Cahiers $d u$ MONDE RUSSE

\section{Cahiers du monde russe}

Russie - Empire russe - Union soviétique et États indépendants

$58 / 3 \mid 2017$

Les terres de l'orthodoxie au XVIIe siècle

\title{
L'encadrement paroissial dans la métropolie de Kiev
}

Inerties, adaptations et transformations à l'âge des réformes religieuses (années 1590 - années 1680)

Parishes of the Kievan metropolitanate from the Union with Rome to its subordination to the Moscow Patriarchate (1590s-1680s)

\section{Laurent Tatarenko}

\section{(2) OpenEdition}

\section{Journals}

Édition électronique

URL : http://journals.openedition.org/monderusse/10094

DOI : $10.4000 /$ monderusse. 10094

ISSN : $1777-5388$

Éditeur

Éditions de l'EHESS

Édition imprimée

Date de publication : 1 juillet 2017

Pagination : 271-302

ISBN : 978-2-7132-2697-7

ISSN : $1252-6576$

\section{Référence électronique}

Laurent Tatarenko, «L'encadrement paroissial dans la métropolie de Kiev », Cahiers du monde russe [En ligne], 58/3 | 2017, mis en ligne le 01 juillet 2019, consulté le 06 janvier 2021. URL : http:// journals.openedition.org/monderusse/10094; DOI : https://doi.org/10.4000/monderusse.10094 


\title{
L'ENCADREMENT PAROISSIAL DANS LA MÉTROPOLIE DE KIEV
}

\author{
Inerties, adaptations et transformations \\ à l'âge des réformes religieuses \\ (années 1590 - années 1680)
}

L'histoire de la métropolie de Kiev au XvII ${ }^{\mathrm{e}}$ siècle offre un aperçu unique sur la vie paroissiale des Églises slaves de rite oriental. En effet, la proclamation de l'Union de Brest en 1595-1596, qui plaça officiellement la hiérarchie orthodoxe de Pologne-Lituanie dans l'obédience de la papauté, déboucha rapidement sur une concurrence obstinée entre les clercs ruthènes ${ }^{1}$, partisans et opposants de ce changement juridictionnel, et, au-delà, sur des tensions entre leurs protecteurs respectifs. Les divers aspects du fonctionnement des structures ecclésiastiques orientales ressortent ainsi en filigrane dans la documentation laissée par les interminables procédures judiciaires pour le contrôle des bénéfices. Ils apparaissent aussi dans les exemples épars, insérés dans les ouvrages de controverse, qui donnent corps aux mentions extraites des sources normatives, peu nombreuses et généralement laconiques sur l'application concrète des mesures énoncées. Toutefois, non seulement ces informations se trouvent très dispersées dans les archives conservées aujourd'hui, mais encore les réalités auxquelles elles renvoient se révèlent souvent éparpillées chronologiquement et spatialement ${ }^{2}$.

1. Le terme « Ruthènes » désignait les chrétiens de rite oriental, héritiers des populations de la Rus' de Kiev médiévale, devenus à partir de la fin du XIV siècle les sujets du royaume de Pologne et de la grande-principauté de Lituanie. Après l'Union de Brest, ce qualificatif renvoya à la fois aux fidèles des Églises orthodoxe et uniate originaires de cet espace.

2. Au moment de l'extension maximale de la République polono-lituanienne vers le milieu du $\mathrm{XVII}^{\mathrm{e}}$ siècle, la superficie de la métropolie de Kiev s'élevait à environ 700000 kilomètres carrés, soit un territoire à peu près équivalent à une fois et demie la taille du royaume de France de la même période. Ce vaste ensemble qui regroupait des régions très diverses n'était divisé qu'en neuf diocèses, y compris l'évêché uniate de Smolensk, dont l'existence dura moins de trente ans, entre 1625 et 1654 (Б.Н. Флоря, « Положение православного населения Смоленщины 
Ces raisons amenèrent la plupart des spécialistes à se tourner vers une documentation sérielle, datée majoritairement du XVIII ${ }^{\mathrm{e}}$ siècle et produite le plus souvent par l'Église uniate. Leurs travaux aboutirent à différentes études régionales ou locales, qui proposent une vision centrée sur la géographie historique, mettant en évidence les évolutions territoriales des structures ecclésiastiques ${ }^{3}$. Pour autant une telle approche laisse en suspens la question des pratiques associées à l'exercice de la charge pastorale, alors même que le clergé kiévien s'engagea à partir de la fin du XVI ${ }^{\mathrm{e}}$ siècle dans un mouvement de réforme institutionnelle, censée à la fois rendre plus efficaces les rapports hiérarchiques internes et améliorer l'encadrement des fidèles ${ }^{4}$. Les conséquences de ces élans réformateurs furent la proclamation de l'Union censée étayer les actions de l'épiscopat et, à terme, l'émergence progressive d'une nouvelle frontière du monde orthodoxe à travers les fissures nées du schisme local de l'Église ruthène.

Comprendre cet éloignement réciproque conduit d'une part à dépasser les simples estimations chiffrées, inévitablement lacunaires, et, d'autre part, à s'écarter des figures rhétoriques de la controverse pour scruter localement les empreintes laissées par cette redéfinition des communautés. La paroisse ruthène devient alors bien plus qu'un simple rouage de l'institution ecclésiastique et s'affirme comme le lieu privilégié pour observer les bouleversements religieux, qui, dans le contexte polono-lituanien, se dessinent à travers le rapport étroit aux modèles produits par les confessions concurrentes. Ce regard en miroir invite également à évaluer le poids des divers facteurs dans l'affirmation des spécificités locales de chacune des Églises slaves de rite oriental, aussi bien là où elles constituaient l'une des minorités de l'éventail religieux, notamment dans les Balkans, que dans la Moscovie du

в составе Речи Посполитой (20-е - 40-е годы XVII в.) » [B.N. Florja, La situation de la population orthodoxe de la région de Smolensk, rattachée à la République polono-lituanienne (années 20 à 40 du XVII ${ }^{\mathrm{e}}$ siècle)], Revue des Études slaves, 70 (2), 1998, p. 333-345).

3. Le travail le plus complet, qui présente toutes les confessions du royaume de Pologne à la veille des partages, est dû à Bogumił Szady : Geografia struktur religijnych $i$ wyznaniowych $w$ Koronie $w$ II polowie XVIII wieku [La géographie des structures religieuses et confessionnelles de la Couronne dans la seconde moitié du XVIII ${ }^{\mathrm{e}}$ siècle], Lublin : Wydawnictwo KUL, 2010. Cette étude intègre et corrige les données rassemblées pour les Églises orientales dans : W. Kołbuk, Kościoły wschodnie w Rzeczypospolitej około 1772 roku [Les Églises orientales dans la République polono-lituanienne vers 1772], Lublin : IEŚW, 1998.

4. Ces transformations sont mieux étudiées pour l'Église latine, grâce aux recherches menées par Stanisław Litak (S. Litak, Parafie w Rzeczypospolitej $w$ XVI-XVIII wieku [Les paroisses dans la République polono-lituanienne des $\mathrm{XVI}^{\mathrm{e}}-\mathrm{XVIII}{ }^{\mathrm{e}}$ siècles], Lublin : KUL, 2004). Les problèmes relatifs à la vie des desservants de rite oriental commencent toutefois à émerger dans les travaux récents des historiens ukrainiens, polonais et bélarusses. Voir notamment : A. Gil, I. Skoczylas, Kościoly wschodnie $w$ państwie polsko-litewskim w procesie przemian i adaptacji : metropolia kijowska w latach 1458-1795 [Les Églises orientales dans l'État polono-lituanien, en voie de transformation et d'adaptation : la métropolie de Kiev dans les années 1458-1795], Lublin : IEŚW, 2014. Pour le clergé orthodoxe du diocèse de L'viv, peu avant son passage à l'Union, voir : P. Wawrzeniuk, Confessional Civilising in Ukraine : The Bishop Iosyf Shumliansky and the Introduction of Reforms in the Diocese of Lviv (1668-1708), Huddinge : Södertörns högskola, 2005 ; Д.В. Лісейчыкаў, Святар у беларускім соиыуме : прасапаграфія ўніяцкага духавенства 1596-1839 г2. [D.V. Lisejčykaw, Le prêtre dans le contexte social bélarusse : prosopographie du clergé uniate dans les années 1596-1839], Minsk : Belarus', 2015. 
$\mathrm{XVII}^{\mathrm{e}}$ siècle, devenue de fait le seul territoire d'Europe administré par un pouvoir orthodoxe indépendant ${ }^{5}$. Faut-il en effet voir les singularités de la vie paroissiale de la métropolie de Kiev comme un reflet des hiérarchies sociales polonolituaniennes, une assimilation plus ou moins voilée de certaines normes latines ou une conséquence de la compétition entre les clergés uniates et orthodoxes, engagés dans un véritable boundary work ${ }^{6}$, avec l'intention de s'attribuer une légitimité exclusive ? Plus encore, est-il possible de saisir les structures paroissiales ruthènes à l'aide des critères latins, qui imposent une grille de lecture relativement rigide, fondée sur un territoire et une juridiction bien définis ? Enfin, comment inscrire la vie paroissiale des chrétiens orientaux polono-lituaniens dans les évolutions générales de la période ${ }^{7}$ ?

La fin du XVII ${ }^{\mathrm{e}}$ siècle apparaît indéniablement comme un moment de basculement dans les équilibres longtemps mouvants et les imaginaires propres aux communautés slaves orientales. Le schisme des vieux-croyants à partir des années 1650 , l'intégration de la métropolie orthodoxe de Kiev à l'Église moscovite en 1686, le «triomphe » tardif de l'Union en Pologne-Lituanie (avec le passage de trois des quatre diocèses orthodoxes ruthènes dans l'obédience pontificale entre 1691 et 1702), sa proclamation en Transylvanie dans les années 1697-1701 et, plus généralement, l'avancée du pouvoir Habsbourg dans les Balkans indiquent implicitement une réduction drastique des interstices entre les confessions, qui, jusque-là, laissaient encore une place suffisante pour une position d' « entre-deux ». Le constat de cette redéfinition des frontières religieuses amène à rechercher ses traces à l'intérieur même des communautés des fidèles. Les structures paroissiales de la métropolie de Kiev demeurèrent-elles un espace à l'écart des controverses, avant de céder peu à peu à un contrôle plus étroit des élites ecclésiastiques, ou furent-elles, inversement, le lieu de production des redécoupages identitaires, sous l'effet des conflits issus de la coexistence quotidienne?

Ces hypothèses invitent à adopter une démarche multiscalaire, croisant des analyses relatives à l'ensemble du clergé kiévien avec l'observation d'un échan-

5. Le cas moscovite bénéficia récemment d'une analyse détaillée grâce au travail de Pëtr Stefanovič : П.С. Стефанович, Приход и приходское духовенство в России в ХVI-XVII веках [P.S. Stefanovič, La paroisse et le clergé paroissial en Russie aux XVI ${ }^{\mathrm{e}}-\mathrm{XVII}{ }^{\mathrm{e}}$ siècles], M. : Indrik, 2002. Elle peut être complétée par des études plus locales : Д.А. Баловнев, « Приходское духовенство XV-начала XVI века по новгородским писцовым книгам (численность и особенности состава) » [D.A. Balovnev, Le clergé paroissial du $\mathrm{Xv}^{\mathrm{e}}$ et du début du $\mathrm{XVI}^{\mathrm{e}}$ siècle, d'après les livres fonciers de Novgorod (effectifs et particularités de sa composition)], Отечественная история, 4 (2004), p. 131-139 ; Е.Д. Суслова, Церковно приходская система в Карелии кониа XV-начала хVIII века [E.D. Suslova, Le système paroissial en Carélie (fin du XV ${ }^{\mathrm{e}}$ siècle - début du XVIII ${ }^{\mathrm{e}}$ siècle], Petrozavodsk : PetrGU, 2013.

6. Ce phénomène formalisé par le sociologue Thomas F. Gieryn fut notamment utilisé en histoire religieuse par Keith Luria à partir de l'exemple des catholiques et des huguenots poitevins (K.P. Luria, Sacred Boundaries : Religious Coexistence and Conflict in Early-Modern France, Washington, DC : CUA Press, 2005).

7. Une présentation détaillée des évolutions religieuses du territoire polono-lituanien à la suite des réformes protestantes est donnée dans : A. Jobert, De Luther à Mohila : la Pologne dans la crise de la chrétienté, 1517-1648, P. : Institut d'études slaves, 1974. 
tillon local, issu de la partie lituanienne du diocèse métropolitain. À partir des exemples issus de la partie lituanienne du diocèse métropolitain cette approche permet de faire ressortir la spécificité du corpus archivistique disponible pour la reconstruction de l'encadrement ecclésiastique ruthène ${ }^{8}$. Elle pose également le problème de la définition de l'institution paroissiale de « rite grec », dont les contours émergent à l'intérieur des rapports socio-économiques complexes entre les patrons, les fidèles et la hiérarchie diocésaine. Enfin les changements entraînés par la division entre uniates et orthodoxes exigent d'évaluer le degré de consolidation de deux « cultures confessionnelles ${ }^{9}$ distinctes dans les imaginaires réciproques, mais aussi dans les pratiques sociales et institutionnelles de chacune des Églises ruthènes.

\section{Des empreintes documentaires d'une structure éclatée}

Si le fonctionnement du réseau paroissial reste encore mal connu pour la métropolie de Kiev, les sources disponibles pour ce territoire se révèlent incontestablement plus riches que celles des autres Églises chrétiennes orientales de la même période. Cette singularité renvoie à l'existence de protocoles des visites pastorales, qui apparurent précocement dans les diocèses ruthènes au cours de la première moitié du XVII ${ }^{\mathrm{e}}$ siècle, puis se généralisèrent sur l'ensemble de l'espace métropolitain après le synode uniate de Zamość de $1720^{10}$. Le recours

8. Après 1415 et la constitution d'une métropolie kiévienne indépendante des métropolites moscovites, les premiers dignitaires de l'Église ruthène prirent l'habitude de résider dans les régions centrales de la grande-principauté de Lituanie (essentiellement à Navahrudak et à Vilnius), ne se rendant que rarement à Kiev. À partir du XVII ${ }^{\mathrm{e}}$ siècle, ils disposaient également d'une église cathédrale à Minsk.

9. Une réflexion théorique sur l'usage de cette notion est présentée dans : P. Büttgen, «Qu'est-ce qu'une culture confessionnelle ? Essai d'historiographie (1998-2008) », in P. Büttgen, C. Duhamelle, dir., Religion ou confession : un bilan franco-allemand sur l'époque moderne (XVI ${ }^{e}-X V I I I^{e}$ siècles), P. : Éditions de la Maison des sciences de l'homme, 2010, p. 415-437.

10. Voir I. Скочиляс, « Генеральні візитації в українсько-білоруських єпархіях Київської митрополії. 1596-1720 роки » [I. Skočyljas, « Les visites générales dans les diocèses ukrainiens et bélarusses de la métropolie de Kiev (années 1596-1720) »], Запискu наукового товариства ім. Шевченка, 238, 1999, p. 46-94; même s'il existe des mentions des visites pastorales ruthènes pour le début du XVI ${ }^{\mathrm{e}}$ siècle, elles restent des cas isolés et très mal connus. De nouvelles attestations ne réapparaissent qu'en 1628, avec la visite menée par le métropolite uniate Józef Rutski lui-même, dans la voïvodie de Volhynie (A. Šeptyckyj, éd., Monumenta Ucrainae Historica, vol. 9-10, Rome : Editiones universitatis catholicae Ucrainorum, 1971, $\mathrm{n}^{\circ}$ 611, p. 714-718). Au même moment, de telles pratiques s'implantèrent dans d'autres évêchés uniates, comme à Chełm en 1633 (A. Gil, « Chełmskie diecezje obrządku wschodniego. Zagadnienie organizacji terytorialnej w XVII i XVIII wieku [Les diocèses de Chełm de rite oriental. Le problème de l'organisation territoriale aux XVII ${ }^{\mathrm{e}}$ et XVIII ${ }^{\mathrm{e}}$ siècles] » in S. Stępień, éd., Polska-Ukraina, 1000 lat sąsiedztwa [Pologne-Ukraine, 1000 ans de voisinage], t. 5, Przemyśl : Południowo-Wschodni Instytut Naukowy w Przemyślu, 2000, p. 31-33) ou à Volodymyr (А. Гіль, І. Скочиляс, éds., Генеральні візитації церков $i$ монастирів Володимирської унійної єnархї̈ [A. Gil, I. Skočyljas, éds., Les visites générales des églises et des monastères du diocèse uniate de Volodymyr], Lublin-L'viv : IEŚW/ УKУ, 2012, p. LXI). 
à cette documentation correspondait à une forme d'assimilation des pratiques latines par le clergé uniate, mais avait aussi laissé des traces dans les rangs orthodoxes. À l'époque du métropolite Piotr Mohyła"11 (1633-1647), les orthodoxes polono-lituaniens introduisirent des pratiques similaires dans leur fonctionnement interne, mais les éventuelles archives produites par ces initiatives ne furent pas conservées ${ }^{12}$. Surtout, la difficulté principale provient d'une barrière chronologique, car les premières visites pastorales ruthènes conservées ne datent que des années 1680-169013.

Une autre source d'information sérielle provient des registres du cathedraticum (katedratyk) ou "куниче », versé à l'évêque pour les prêtres de son diocèse et destiné à assurer son entretien. Même si cette documentation devait fournir l'image la plus complète du clergé paroissial, son analyse révèle que ces redevances suscitaient des oppositions et n'étaient payées que par une faible partie du clergé. De plus, alors que cette pratique existait dans la métropolie kiévienne depuis le XIII ${ }^{\mathrm{e}}$ siècle, les premiers « livres du cathedraticum » parvenus jusqu'à nous ne datent, là encore,

11. Pour la graphie des noms propres, il est particulièrement difficile d'adopter une norme unique car, en dehors du problème de la translittération, chaque historiographie nationale fait généralement le choix d'employer la forme transposée dans la langue de son pays d'origine. Une telle solution devient toutefois délicate dès qu'on sort des cadres des langues slaves (bien qu'elle soit pratiquée en Lituanie) et crée des anomalies par la juxtaposition de normes linguistiques trop éloignées l'une de l'autre. Plus encore, elle impose des cadres politiques et géographiques arbitraires pour la période étudiée dans l'article. En particulier, pour les personnages d'origine ruthène, le choix entre la forme bélarusse ou ukrainienne se révèle généralement impossible. Dans l'intention de veiller à l'homogénéité du propos, tout en réduisant la part des anachronismes, l'article propose de suivre une double distinction chronologique et géographique, qui se rapproche des usages administratifs de l'époque. Pour les non-Ruthènes 1) Les noms des souverains (y compris les papes et les patriarches) suivent la forme française communément employée 2) les noms des individus étrangers à la Pologne-Lituanie (Italiens, Moscovites, etc.) sont présentés dans leur forme "nationale » actuelle 3) les noms des sujets polono-lituaniens adoptent la version polonaise. Pour les Ruthènes 1) les noms antérieurs à l'Union de Lublin (1569) sont présentés dans la version ruthène « ukrainienne » (la plus largement utilisée dans l'historiographie occidentale) 2) les personnages postérieurs à la promulgation de la République polono-lituanienne sont cités sous la forme polonaise (même si l'auteur a conscience que la langue ruthène ne disparut définitivement de la chancellerie de la grande-principauté de Lituanie qu'en 1697) 3) les Ruthènes installés sur le territoire de l'Hetmanat (après 1648) font l'objet d'une exception et sont également mentionnés d'après la forme ukrainienne.

12. А. Жуковський, Петро Могила й питання єдности Церков [A. Žukovs'kyj, Piotr Mohyła et la question de l'Union des Églises], Kiev : Mistectvo, 1997, p. 99. Des registres furent toutefois conservés pour le diocèse de Mahilew dans les années 1730 (I. Скочиляс, “ “Дар любові”, фіскальний обов' язок і єрархічна підлеглість: катедратик у системі фінансово-корпоративних відносин духовенства Київської митрополії XIII-XVIII століть » [I. Skočyljas, « Le "don d'amour", les obligations fiscales et la soumission hiérarchique : le cathedraticum dans le système des rapports fiscaux et corporatifs du clergé de la métropolie de Kiev, aux XIII ${ }^{\mathrm{e}}$-XVIII ${ }^{\mathrm{e}}$ siècles »], Дрогобицький краєзнавчий збірник, 9, 2005, p. 435). En Russie, la diffusion d'un premier équivalent aux protocoles des visites pastorales catholiques, désigné sous le terme de « клировские ведомости », ne commença véritablement dans l'Eglise orthodoxe (russe) qu'à partir de 1829.

13. Д.В. Лісейчыкаў, éd., Візіты уніяцкіх иэркваў Мінскага і Навагрудскага сабораў 1680-1682 г2. : Зборнік дакументаў [D.V. Lisejčykaw, éd., Les visites pastorales des églises des circonscriptions de Minsk et de Navahrudak dans les années 1680-1682 : recueil de documents], Minsk : I.P. Logvinau, 2009 ; Гіль, Скочиляс, éd., Генеральні візитації. 
que des années $1680^{14}$. Ce moment paraît correspondre à un véritable pallier dans l'évolution de l'outillage administratif des Églises ruthènes des deux obédiences ou, du moins, à une amélioration de leurs pratiques archivistiques; il forme une limite dans l'étude de l'encadrement paroissial. La chronologie particulière de cette évolution documentaire amène - d'une manière peu conventionnelle pour l'historien - à rechercher des informations à rebours, dressant le tableau d'une époque plus récente, avant d'essayer de retrouver des indications plus anciennes à travers les pistes ainsi dégagées. Pour les différentes régions de la métropolie de Kiev, le point de départ se situe généralement dans les années 1770-1780, soit une époque pour laquelle les archives conservent des estimations détaillées pour presque l'ensemble du territoire concerné. Les estimations les plus récentes évaluent ainsi à près de 10300 le nombre total des paroisses ruthènes, uniates et orthodoxes, pour l'ensemble de la République polono-lituanienne ${ }^{15}$. La situation de la partie du diocèse métropolitain orthodoxe, placée sur le territoire de l'Hetmanat, fut récemment analysée par Oksana Prokop'juk ${ }^{16}$.

Pour la période antérieure, les premières données chiffrées proposées par les contemporains, produites par l'Église ruthène, renvoient aux estimations énoncées en 1595 par l'ambassade ruthène à Rome ${ }^{17}$. Dans les discussions avec les prélats de la Curie, les évêques kiéviens prétendirent que la métropolie comptait près de 12000 paroisses ${ }^{18}$. Plus tard, ils révisèrent leurs données en affirmant que les diocèses dont les évêques étaient déjà acquis à l'Union comportaient près de 8000 paroisses et qu'il y en avait presque autant dans les deux diocèses de L'viv

14. Скочиляс, « “Дар любові”... », p. 437.

15. Diocèse métropolitain: 2716 paroisses, diocèse de L'viv-Halyč-Kamen'janec' : 2721 paroisses, diocèse de Przemyśl: 1310 paroisses, diocèse de Luc'k-Ostroh: 1163 paroisses, diocèse de Polack : 601 paroisses, diocèse de Chełm-Belz : 561 paroisses (y compris les 12 églises monastiques), diocèse de Volodymyr-Brest: 489 paroisses, Pinsk-Turaw : 238 paroisses. Les orthodoxes possédaient à la même époque 267 paroisses dans le diocèse de Mahilew-Orša-Mscislaw et 230 paroisses dans le diocèse métropolitain de Kiev. W. Kołbuk, Kościoły wschodnie, p. 47, 70 ; A. Gil, Chetmska diecezja unicka 1596-1810 : dzieje i organizacja [Le diocèse uniate de Chetm (1596-1810) : histoire et organisation], Lublin/Chełm : IEŚW, 2005 ; Szady : Geografia struktur, p. 222 ; W. Walczak, The Structure of the Uniate Turaŭ-Pinsk Eparchy in the $17^{\text {th }}$ and $18^{\text {th }}$ Centuries, Białystok : Instytut badań nad dziedzictwem kulturowym Europy, 2013.

16. О. Прокоп'юк, Киїська митрополія: топографія посвят. Реконструкиія реєстру храмів за відомостями про церковнослужителів (1780-1783) [O. Prokop'juk, La métropolie de Kiev : topographie des consécrations. La reconstruction du registre des sanctuaires d'après les bulletins des desservants ecclésiastiques (1780-1783)], Kiev : DP « NVC Prioriteti », 2012. À cette période, le diocèse métropolitain orthodoxe dénombrait un peu moins de 970 lieux de culte.

17. La mission fut confiée aux évêques de Volodymyr et de Luc'k, Hipacy Pociej et Cyryl Terlecki.

18. Ce chiffre fut retenu par Cesare Baronio dans l'extrait de ses Annales ecclésiastiques, consacrées à l'ambassade ruthène, qui fut réimprimé en 1598, à Ingolstadt, sous le titre de Legationes Alexandrina et Ruthenica ad Clementem VIII (l'information y figure à la page 33). 
et de Przemyśl, dont les hiérarques restaient hésitants, mais dont ils espéraient le ralliement ${ }^{19}$.

Vers le milieu du XVII ${ }^{\mathrm{e}}$ siècle, les valeurs chiffrées réapparurent dans les relations envoyées à la Propaganda Fide par les métropolites, les évêques ou le procureur des moines basiliens à Rome. Ces textes prirent une forme plus détaillée, moins sous l'effet d'une meilleure connaissance du territoire que pour répondre aux exigences de la Curie, soucieuse d'avoir une information plus fiable et actualisée. Les difficultés matérielles et les affrontements militaires des années 1650-1660 empêchèrent cependant de mener de véritables enquêtes locales.

Ces documents mêlaient donc des observations faites sur le terrain aux estimations peu fondées et aux affirmations des différents hiérarques uniates du premier $\mathrm{XVII}^{\mathrm{e}}$ siècle, qui avaient fini par façonner et, à terme, figer l'apparence supposée du réseau paroissial ruthène. 
Tableau 1 : Le réseau paroissial ruthène d'après les relations uniates du milieu du XVII ${ }^{e}$ siècle

\begin{tabular}{|l|r|r|r|}
\hline \multicolumn{1}{|c|}{ Diocèse } & $\begin{array}{c}\mathbf{1 6 4 7} \\
\text { (Filip Borowyk) }^{\mathbf{2 0}}\end{array}$ & $\begin{array}{c}\text { 1664 } \\
\text { (Jakub Susza) }^{\mathbf{2 1}}\end{array}$ & $\begin{array}{c}\text { 1671 } \\
\text { (Gabriel Kolenda) }^{\mathbf{2 2}}\end{array}$ \\
\hline Métropolie : & 2000 & - & - \\
\hline $\begin{array}{l}\text { - grande-principauté } \\
\text { de Lituanie }\end{array}$ & - & 600 & $1000-2000 ?$ \\
\hline - Couronne & - & - & 8000 \\
\hline Polack-Vicebsk & 2200 & 1000 & $2000-3000 ?$ \\
\hline Pinsk-Turaw & 500 & 100 & - \\
\hline Brest-Volodymyr & 1000 & 1000 & - \\
\hline L'viv-Halyč & 3000 & - & 6000 \\
\hline Chełm-Belz & 900 & 700 & - \\
\hline Luc'k-Ostroh & 1000 & $100 \mathrm{a}$ & 5000 \\
\hline Przemyśl-Sambir & 4000 & 3000 & 5000 \\
\hline Smolensk & 800 & $600 \mathrm{~b}$ & - \\
\hline
\end{tabular}

20. A. Welykyj, éd., Litterae Basilianorum Historiam Ucrainae illustrantes, t. 1, Rome : P.P. Basiliani, 1979, n²9, p. 51-61. À cette époque, Filip Borowyk se trouvait déjà depuis quatorze ans à Rome où, après avoir achevé ses études au Collège grec en 1638, il exerçait la charge de procureur basilien. Son rapport fortement hostile au métropolite, qui était alors en conflit avec l'ordre basilien, cherchait à dénoncer les méfaits produits par la mauvaise administration de Sielawa et lui reprochait d'avoir laissé inoccupées une grande partie des paroisses évoquées.

21. A. Welykyj, éd., Litterae Episcoporum Historiam Ucrainae illustrantes, t. 2, Rome : P.P. Basiliani, 1973, n 181, p. 296-335. Les estimations de l'évêque de Chełm, Jakub Susza, étaient insérées dans sa vaste relation intitulée « De laboribus unitorum » (1664), dont l'intention était de montrer la ténacité des uniates, à une époque particulièrement difficile pour leur Église. Mêlant les indications pour les uniates et les orthodoxes, il dénombrait au moins 7100 paroisses de rite grec mais précisait qu'avant les troubles de la mi-XVII ${ }^{\mathrm{e}}$ siècle, les premiers possédaient plus de 8000 paroisses. Là encore, même si Susza avait une bonne connaissance de l'état de son propre diocèse, il est facile de remarquer que, pour l'ensemble de la métropolie, il reprenait le chiffre « traditionnel », répété à plusieurs reprises depuis la fin du XVI ${ }^{\mathrm{e}}$ siècle.

22. A. Welykyj, éd., Epistolae Metropolitarum, t. 2, n 81, p. 302-329. Si les données rassemblées par le métropolite uniate Gabriel Kolenda font état d'une estimation bien supérieure à celles proposées précédemment, ses indications ne correspondaient à aucun recensement réel. Les formules utilisées dans le document révèlent d'ailleurs que le métropolite n'émettait ici qu'une simple supposition : «l'étendue de l'archevêché de Polack, Vicebsk, Mscislaw et de la métropolie de Kiev (celle qui est circonscrite à la grande-principauté de Lituanie, car la métropolie de Kiev, qui s'étend à la région de Kiev et à l'Ukraine, gémit jusqu'ici sous la juridiction schismatique) est telle qu'elle pourrait compter facilement quatre mille paroisses [...] » (Ibid., p. 304). Il semblerait donc que Kolenda se contentait de reprendre les propos inscrits dans la relation de Filip Borowyk, dont l'estimation renvoyait toutefois à l'ensemble du diocèse métropolitain, avec ses régions méridionales : « on dit que le diocèse métropolitain, avec les évêchés, possède quatre ou cinq mille églises » (Welykyj, éd., Litterae Basilianorum, t. 1, n² 29, p. 53). De même, il ne paraît pas fallacieux de voir dans le chiffre chimérique des huit mille sanctuaires attribués à la partie orthodoxe du diocèse métropolitain, une référence aux affirmations de l'ambassade ruthène à Rome ou à la relation bien plus récente de Jakub Susza. À l'image de ses prédécesseurs, Kolenda agissait ici en compilateur scrupuleux, mais bien peu critique, des sources hétéroclites qui se trouvaient à sa disposition. 


\begin{tabular}{|l|r|r|r|}
\hline Mahilew-Orša-Mscislaw & - & - & $70 \mathrm{c}$ \\
\hline Černihiv & - & - & 2000 \\
\hline Total & $15400(18000 \mathrm{~d})$ & $7100(8000 \mathrm{~d})$ & - \\
\hline
\end{tabular}

${ }^{a}$ : Valeur correspondante aux seules paroisses orthodoxes, d'après l'auteur.

b : Le diocèse de Smolensk fut conquis par les troupes moscovites en octobre 1654 et confirmé à la Russie par le traité d'Andrusovo de 1667.

c : Chiffre pour l'ensemble des paroisses orthodoxes de la grande-principauté de Lituanie qui ne possédait à l'époque qu'un seul évêché dans l'obédience de Constantinople.

d: Estimation donnée par l'auteur.

Aux côtés des archives ecclésiastiques, l'enquête peut s'appuyer également sur les diverses sources séculières, produites par les institutions princières ${ }^{23}$. Le premier ensemble renvoie aux diverses révisions (lustracje) des domaines et, surtout, aux registres fiscaux relatifs aux redevances réelles ou personnelles, qui connurent une croissance au cours du XVII ${ }^{\mathrm{e}}$ siècle, par suite des guerres récurrentes entre la République et ses voisins. Les analyses faites à partir d'échantillons locaux révèlent que les registres des fouages (podymne) ${ }^{24}$ et de la capitation (pogłówne) $)^{25}$, qui regroupent dans une catégorie particulière les prêtres de « rite grec » d'un district (powiat), apportent une perspective régionale pertinente mais souvent incomplète du réseau paroissial ${ }^{26}$.

L'autre groupe documentaire est formé de la masse des actes notariés, conservée dans les Registres (Metryka) de la Couronne et de la grande-principauté de Lituanie ou par les tribunaux nobiliaires et urbains (sady ziemskie et grodzkie), dans les villes qui jouissaient du privilège du droit de Magdebourg (sądy burmistrzowskieradzieckie et sądy wójtowkie $)^{27}$. En effet, en dehors de leurs fonctions premières

23. L'étude des paroisses sur l'espace moscovite fait appel à une documentation similaire avec les livres fonciers (piscovye knigi) et les recensements (perepisnye knigi), qui apparaissent dans les années 1640 .

24. Impôt adopté en 1629 par la Diète et étendu en 1649 au territoire lituanien. Voir A. Rachuba, éd., Metryka Litewska. Rejestry podymnego Wielkiego Księstwa Litewskiego. Województwo wileńskie $1690 r$. [Le Grand Registre lituanien. Les registes des fouages de la grande-principauté de Lituanie. La voïvodie de Vilnius en 1690], Varsovie : PWN, 1989.

25. M. Kopczyński, « Subsidium charitatiuum 1662 r. Uchwała i wykonanie [Le subsidium charitativum de 1662. Adoption et mise en pratique] », Miscellanea Historico-Archivistica, 11, 2000, p. 253-265. La capitation était un impôt normalement prélevé sur les Juifs, les Tatares et d'autres minorités considérées comme " étrangères », en échange de la protection du souverain. Toutefois, au XVI ${ }^{\mathrm{e}}$, le prélèvement devint aussi une forme d'impôt extraordinaire, destiné aux besoins militaires de l'État et étendu au clergé et à la noblesse. Dans la seconde moitié du $\mathrm{XVII}^{\mathrm{e}}$ siècle, les guerres et les destructions provoquées sur le territoire de la République poussèrent la Diète à voter à plusieurs reprises la levée de cette contribution. Pour les nobles et les clercs, la capitation était désignée sous le terme de subsidium charitatiuum.

26. Pour la voïvodie de Vilnius, une comparaison de la liste de toutes les paroisses ruthènes recensées à partir de diverses sources disponibles pour ce territoire, avec celles mentionnées dans les registres fiscaux des années 1670-1680, conservées dans les Archives historiques lituaniennes d'État [Lietuvos Valstybes Istorijos Archyvas], montre un résultat inégal. Y figurent $63,9 \%$ des paroisses pour le district d'Ašmjany, 73,7 \% pour celui de Lida, 82,4 \% pour celui de Braslaw et, enfin, seulement 33,3 \% pour celui de Hrodna.

27. Cette documentation a été utilisée par Mykola Hruševs'kyj dans son travail précurseur sur le clergé rural ruthène de la première moitié du $\mathrm{XVI}^{\mathrm{e}}$ siècle, à partir du cas de la région 
administratives ou judiciaires, ces institutions possédaient une compétence notariale, et conservaient les copies d'actes privés, présentés par les personnes concernées pour les faire enregistrer et les faire confirmer de la sorte par les instances officielles. Ces lieux devenaient une forme de dépôt d'archives de l'Église kiévienne, y compris pour les clercs paroissiaux, qui y faisaient inscrire les documents relatifs aux bénéfices rattachés à leurs églises.

Ce vaste corpus constitue indéniablement la source la plus riche en informations sur l'état des structures ecclésiastiques locales, avant la généralisation des visites pastorales. Il permet également de remonter à des époques plus anciennes, allant parfois jusqu'à la fin du $\mathrm{XV}^{\mathrm{e}}$ siècle. Toutefois, son étude se révèle souvent délicate, car elle est étroitement liée aux hasards de la conservation et des dépouillements rendus laborieux par une classification chronologique, qui impose la consultation attentive de chaque volume avec des résultats inégaux. C'est pourquoi son utilisation ne peut intervenir que pour un espace restreint et une période chronologique bien délimitée ${ }^{28}$.

En somme, la reconstruction du réseau paroissial ruthène au $\mathrm{XVII}^{\mathrm{e}}$ siècle exige de mettre en parallèle la documentation ecclésiastique et les différentes sources séculières afin de constituer une cartographie locale avec des marges d'erreur acceptables $^{29}$. Une vue d'ensemble de la métropolie exigerait donc de juxtaposer les études régionales, mais les enquêtes actuellement disponibles sont loin de couvrir l'ensemble du territoire concerné. Toutefois, pour l'extrême fin du XVI ${ }^{\mathrm{e}}$ siècle, qui correspond au début de notre enquête, les analyses récentes permettent déjà d'esquisser un premier bilan représentatif.

de Sambir : M. Грушевський, « Сторінка 3 істориї українсько-руського сїльського духовенства (по самбірським актам хvі в.) [M. Hruševs'kyj, Une page de l'histoire du clergé rural ukraino-ruthène (d'après les actes de Sambir du $\mathrm{XVI}^{\mathrm{e}}$ siècle)] ", Записки Наукового Товариства ім. Шевченка, 34, 1900, р. 1-82.

28. La démarche est toutefois facilitée par les éditions de sources, réalisées à partir du milieu du $\mathrm{XIX}^{\mathrm{e}}$ siècle par les différentes commissions « archéographiques » de l'empire russe instituées à Saint-Pétersbourg, à Kiev et à Vilnius.

29. Une telle approche fut notamment menée pour la Volhynie : М.В. Довбищенко, éd., Документи до історії унї̈ на Волині і Київичні кіния ХVI-периої половини хуII cm. [Dосuments pour l'histoire de l'Union en Volhynie et dans la région de Kiev à la fin du XVI et au début du XVII ${ }^{\mathrm{e}}$ siècles], Kiev : UDNDIASD, 2001. 
Tableau 2 : Le réseau paroissial des évêchés ruthènes de Brest-Volodymyr, Chełm-Belz, L'viv-Halyč, Przemyśl-Sambor et Pinsk-Turaw à la veille de l'Union de Brest ${ }^{30}$

\begin{tabular}{|c|c|c|c|}
\hline Territoire & Nb. de paroisses & $\begin{array}{c}\text { Superficie } \\
\left.(\mathbf{e n ~ k m})^{2}\right)\end{array}$ & $\begin{array}{c}\text { Superficie } \\
\text { moyenne } \\
\text { d'une paroisse } \\
\left(\mathrm{en} \mathrm{km}^{2}\right)\end{array}$ \\
\hline Brest-Volodymyr & $\approx 500$ & 30100 & $\approx 60$ \\
\hline Chełm-Belz & $420-440$ & 18000 & $41-43$ \\
\hline L'viv-Halyč & 1043 & 43318 & 42 \\
\hline Przemyśl-Sambir & $700-750$ & 23600 & $32-34$ \\
\hline Pinsk-Turaw & 182 & 23800 & 130 \\
\hline
\end{tabular}

L'observation du tableau $\mathrm{n}^{\circ} 2$ fait ressortir deux constats importants. Tout d'abord, le territoire de la métropolie de Kiev montrait une importante disparité dans l'encadrement paroissial, entre les territoires de la Couronne et ceux de la grandeprincipauté de Lituanie ${ }^{31}$. D'autre part, si les superficies des paroisses de rite oriental n'étaient que légèrement supérieures aux densités du réseau latin de ces mêmes régions, elles représentaient des ensembles très vastes qui rappellent la situation de certaines zones de montagne de l'Europe occidentale ${ }^{32}$. Face à ces valeurs de départ, sans toutefois renverser ces tendances, le $\mathrm{XVII}^{\mathrm{e}}$ siècle correspondit à une époque de développement des cadres ecclésiastiques avec la constitution de nouvelles paroisses, mais également des modifications dans les frontières diocésaines. Au début du XVIII ${ }^{\mathrm{e}}$ siècle, le diocèse uniate de Chełm disposait déjà d'une cinquantaine de paroisses supplémentaires après avoir repris les territoires méridionaux qui, pendant près de quarante ans, avaient été rattachés à d'autres diocèses voisins ${ }^{33}$.

30. А. Гіль, І. Скочиляс, Володимирсько-Берестейська єпархія хI-ХVIII століть : історичні нариси [Le diocèse de Brest-Volodymyr aux $\mathrm{X}^{\mathrm{e}}$-XVIII ${ }^{\mathrm{e}}$ siècles : esquisse historique], L'viv : [S. n.], 2013, p. 23-32 ; Gil, Chetmska diecezja, 2005, p. 42 ; Z. Budzyński, « Sieć cerkiewna ziemi przemyskiej w świetle rejestru poborowego z 1628 roku [Le réseau paroissial de la région de Przemyśl à la lumière du registre des redevances de 1628] », Rocznik Przemyski, 32 (1), 1996, р. 109-124 ; В.Ф. Кметь, Львівська єпархія у хVI-на початку хуII століття [V. F. Kmet', Le diocèse de L'viv au XVI siècle et au début du XVII ${ }^{e}$ siècle], résumé de la thèse de doctorat, soutenue à l'université nationale de L'viv le 28 mars 2001, p. 14-15 ; W. Walczak, « Il posto della diocesi di Turów e Pińsk nella struttura della Chiesa Uniate dei secc. XVI-XVII », Orientalia Christiana Periodica, 79, 2013, p. 406-428.

31. Ce constat est confirmé par quelques analyses locales de la partie lituanienne du diocèse métropolitain. À l'intérieur des zones défrichées sur lesquelles les Ruthènes constituaient une part importante de la population, dans le district de Hrodna ou dans les parties orientales de la voïvodie de Vilnius, les superficies moyennes des paroisses « de rite grec » atteignaient respectivement 74 et 134 kilomètres carrés.

32. Voir N. Carrier, F. Mouthon, Les paysans des Alpes : les communautés montagnardes au Moyen Âge, Rennes : PUR, 2010, p. 135-142.

33. Gil, Chetmska diecezja, p. 153. 
L'Église orthodoxe fut moins sujette à cet élan de fondations paroissiales car, après 1596, seuls deux évêques kiéviens, ceux de L'viv et de Przemyśl, continuèrent de reconnaître l'obédience de Constantinople. En 1609, la mort de Michał Kopysteński ne laissa plus qu'un évêque orthodoxe pour l'ensemble de la métropolie et cette situation se prolongea jusqu'en 1620, quand le patriarche Théophane de Jérusalem accepta de consacrer une nouvelle hiérarchie épiscopale ruthène ${ }^{34}$. Ce contexte singulier rendait difficile les ordinations de ceux qui pouvaient prendre en charge les nouvelles fondations, mais aussi le remplacement des desservants orthodoxes défunts. Certains candidats à la prêtrise n'hésitaient pas à effectuer de longs voyages jusqu'à L'viv pour y être ordonnés, mais cette pratique entraînait des procédures judiciaires avec les hiérarques uniates et contredisait les normes canoniques qui interdisaient aux évêques d'intervenir à l'extérieur de leurs diocèses ${ }^{35}$. Pour autant, d'après les estimations de Tomasz Kempa, ce même moment apporta une véritable vague de fondations monastiques orthodoxes avec près d'une cinquantaine de créations dans la première moitié du XVII ${ }^{\mathrm{e}}$ siècle. Ce chiffre correspondait alors à la moitié du nombre total des couvents qui continuait à relever de l'obédience constantinopolitaine sur le territoire polono-lituanien ${ }^{36}$.

En 1632, les Articles de pacification promulgués à l'occasion de la montée sur le trône du roi Ladislas IV permirent le rétablissement officiel d'une Église orthodoxe de nouveau reconnue par le pouvoir comme l'une des institutions religieuses de la République $^{37}$. La solution promue par le souverain fixa plus clairement les frontières entre les deux clergés ruthènes, mais les fondations se poursuivirent dans les décennies suivantes ${ }^{38}$. Dans la pratique, il était prévu d'envoyer des commissaires dans les villes importantes du royaume de Pologne et de la grande-principauté de

34. K. Chodynicki, Kościól prawosławny a Rzeczpospolita Polska : zarys historyczny 1370-1632 [L'Église orthodoxe et la République polonaise : étude historique 1370-1632], Varsovie : Kasa im. Mianowskiego-Instytut popierania nauki, 1934, p. 425-431.

35. Акты, издаваемые Виленскою Археографическою коммисиею [Actes édités par la commission archéographique de Vilnius], t. 8, Vilnius, 1875, p. 41-59.

36. T. Kempa, « Fundacje monasterów prawosławnych w Rzeczypospolitej w pierwszej połowie XVII wieku [Les fondations des monastères orthodoxes dans la République au cours de la première moitié du XVII ${ }^{\mathrm{e}}$ siècle] », in A. Mironowicz, U. Pawluczuk, P. Chomik, éds., Życie monastyczne $w$ Rzeczypospolitej [La vie monastique dans la République polonolituanienne], Białystok : Zakład Historii Kultur Pogranicza Instytutu Socjologii Uniwersytetu w Białymstoku, 2001, p. 74-102. Pour une comparaison avec la fin du Xvi ${ }^{\mathrm{e}}$ siècle, voir : P. Chomik, Życie monastyczne w Wielkim Księstwie Litewskim w XVI wieku [La vie monastique dans la grande-principauté de Lituanie au XVI ${ }^{\mathrm{e}}$ siècle], Cracovie : Avalon, 2013.

37. Sur cet épisode et ses conséquences voir : T. Kempa, Wobec Kontrreformacji : protestanci i prawosławni w obronie swobód wyznaniowych w Rzeczypospolitej w końcu XVI $i$ w pierwszej polowie XVII wieku [Face à la Contre-Réforme : protestants et orthodoxes dans la défense des libertés confessionnelles dans la République à la fin du $\mathrm{XVI}^{\mathrm{e}}$ et dans le première moitié du XVII ${ }^{\mathrm{e}}$ siècle], Toruń : Adam Marszałek, 2007, p. 376-552.

38. À titre d'exemple, dans le diocèse de L'viv, le nombre de paroisses passa de 1043 dans les années 1590 à 1578 dans la première décennie du XVIII ${ }^{\mathrm{e}}$ siècle, soit quelques années après son ralliement à l’Union (I. Скочиляс, « Недатований реєстр духовенства, церков і монастирів львівської єпархії за владицтва Йосифа Шумлянського » [I. Skočyljas, « Le registre non daté du clergé, des églises et des monastères du diocèse de L'viv sous Józef Szumlański »], Записки наукового товариства ім. Шевченка, 240, 2000, p. 536-537). 
Lituanie, dotées d'une importante communauté ruthène, afin de partager les sanctuaires de « rite grec » entre les partisans des obédiences romaine et constantinopolitaine. Les édits royaux prévoyaient de procéder à une division scrupuleuse des sanctuaires, puisque dans le cas des voïvodies lituaniennes de Trakai et de Vilnius - où le poids des orthodoxes était pourtant bien plus faible que dans les régions orientales de la Couronne - plusieurs centres locaux devaient accorder une église aux orthodoxes ${ }^{39}$. Pour rééquilibrer partiellement l'emprise territoriale de chacune des Églises ruthènes, un nouvel évêché orthodoxe de Mscislaw-Mahilew-Orša devait être créé sur le territoire oriental de l'archidiocèse uniate de Polack. Enfin les chaires épiscopales de Luc'k et de Przemyśl, avec leurs bénéfices, devaient être transférées à des hiérarques orthodoxes ${ }^{40}$. Le clergé uniate, soutenu par les prélats latins locaux et par Rome, fit plusieurs protestations à la Diète face à un compromis qu'il assimilait à une véritable trahison au profit des " schismatiques » appelés « désunis (dyzunici) » dans la terminologie employée par l'administration princière ${ }^{41}$.

Sans surprise, les partages des bénéfices paroissiaux et des monastères suscitèrent l'hostilité des uniates et aboutirent rapidement à de longs procès en justice, voire à de véritables batailles rangées ${ }^{42}$. En dehors des forces mobilisées par les camps concurrents, le transfert ou non des édifices ecclésiastiques dépendait aussi des équilibres politiques locaux. En témoigne le cas de Vilnius, dominée par les autorités catholiques qui ne permirent jamais aux orthodoxes de prendre possession des trois églises urbaines qui leur avaient été accordées. Ces transformations territoriales créèrent également une situation inouïe dans laquelle la superposition des institutions religieuses n'était plus une question rituelle, comme cela avait été le cas dans la République depuis le XIV ${ }^{\mathrm{e}}$ siècle, mais devenait le signe d'une concurrence juridictionnelle à l'intérieur d'une même communauté de fidèles. Loin de régler les conflits, les cadres introduits par Ladislas IV devenaient une première reconnaissance explicite du schisme local né de l'Union. Dans les faits, celui-ci donnait lieu à l'éclosion de plusieurs enclaves juridictionnelles avec des lieux de culte rattachés à des tutelles lointaines à l'image des orthodoxes de la Lituanie occidentale ou aux uniates des diocèses méridionaux, comme Przemyśl. Un tel affermissement des divisions confessionnelles devenait aussi un facteur de redéfinition des cadres du territoire paroissial.

39. Le texte évoquait les localités de Hrodna, Kaunas, Trakai, Lida, Mjadzel, Lida et Vilnius : С.Г. Рункевичъ, éd., Описаніе документовъ архива западнорусскихъ уніатскихъ митрополитовъ [S.G. Runkevič, Inventaire des documents des archives des métropolites uniates de la Rus' occidentale], t. 1, SPb. : Sinodal'naja Tipografija, 1897, n 616, p. 227-228.

40. Kempa, Wobec Kontrreformacji, p. 410-411.

41. Рункевичъ, éd., Описаніе документовъ, nº68-611, p. 225-226.

42. Kempa, Wobec Kontrreformacji, p. 410-411. Voir aussi les documents publiés dans С.Т. Голубев, Киевский митрополит Петр Могила и его сподвижники [C.T. Golubev, Le métropolite de Kiev Piotr Mohyła et ses contemporains], t. 1-2, Kiev : Tipografija G.T. Korčak-Novickogo/Tipografija S.V. Kul'ženko, 1883-1898. 


\section{Paroisses ou églises?}

Le caractère relativement lâche de l'encadrement ecclésiastique ruthène plaçait chaque lieu de culte dans une position bivalente. Celui-ci renvoyait à une institution centrale des rapports de la communauté des fidèles et, dans le même temps, son éloignement du pouvoir épiscopal en faisait l'un des éléments de la concurrence économique entre les grands propriétaires terriens et une structure profondément influencée par la sociabilité locale. Cet aspect rend parfois délicate la définition même de la "paroisse " ruthène à cette époque. La typologie des sources disponibles pour l'étude de la vie paroissiale dans la métropolie kiévienne porte en elle-même un indice important. Elle montre que jusqu'à une période tardive du XVII ${ }^{\mathrm{e}}$ siècle, seules les fonctions économiques des paroisses uniates ou orthodoxes faisaient l'objet d'une surveillance des patrons et dans une certaine mesure de la hiérarchie ecclésiastique, alors que les fonctions cultuelles laissaient une très large place à l'oralité. Cela ne signifiait pas une absence de continuité dans les usages liturgiques et rituels des desservants, mais rendait bien plus difficile toute tentative de contrôle disciplinaire et de normalisation des pratiques. Au début du XVII ${ }^{e}$ siècle, la conséquence de ce phénomène se reflétait dans l'image du prêtre ruthène ignorant et coupable de nombreux abus, devenue à cette époque un cliché de la rhétorique latine qui, par la dénonciation de cet exemple, cherchait à promouvoir la figure du « bon prêtre », telle qu'elle avait été façonnée par la Réforme tridentine ${ }^{43}$.

Pourtant, cette prétendue décadence cachait surtout de profondes différences structurelles entre les institutions ecclésiastiques latines et celles du christianisme oriental dans les régions slaves. Les premières paroisses orthodoxes étaient apparues sur le territoire de la Rus' de Kiev dès le $\mathrm{XI}^{\mathrm{e}}$ siècle, dans les villes et les différentes résidences princières (погосты), servant d'unités administratives pour la levée de l'impôt ${ }^{44}$. La formation du réseau ecclésiastique, y compris dans les villages, suivit d'abord les fondations des princes locaux qui, à l'origine, furent les détenteurs du droit de patronage laïc (ктиторство) sur toute l'Église ruthène ${ }^{45}$.

43. Une relation de l'évêque de Vilnius, Benedykt Wojna, datée de 1605, affirmait ainsi : « les popes ou prêtres ruthènes par manque de cette discipline, dont nous parlons, sont si incultes qu'ils savent à peine lire et ignorent en tout les formules des sacrements et les offices de la foi ; bien qu'ils soient censés les connaître et les expliquer, ils les accomplissent de manière la plus indigne, avec de nombreuses hérésies » (P. Rabikauskas, éd., Relationes status dioecesium in Magno Ducatu Lituaniae, t. 1, Rome : Academia Lithuana Catholica Scientiarum, 1971, p. 30).

44. Д.А. Баловнев, « Приходское духовенство в Древней Руси. X-хV вв. [Le clergé paroissial dans l'Ancienne Rus', $\mathrm{x}^{\mathrm{e}}-\mathrm{XV}^{\mathrm{e}}$ siècles] ", in Православная эничиклопедия : русская православная Церковь [L'Encyclopédie orthodoxe : l'Église orthodoxe russe], M. : CNC «Pravoslavnaja enciklopedija», 2000, p. 252.

45. Par une habitude désormais largement répandue dans l'historiographie, nous utilisons le terme « droit de patronage » pour traduire ktitorstvo ( doxe. Toutefois, Kazimierz Chodynicki fait remarquer qu'en raison des différences juridiques entre les modèles grec et latin, il serait plus exact de comparer le premier à l'institution de l'avouerie de l'Europe occidentale, avec le droit de protection (mundium) qui lui était associé. Voir Chodynicki, Kościól prawosławny, p. 116-117. Pëtr Stefanovič préfère à son tour faire 
Par conséquent, dès ses origines, la paroisse orthodoxe se développa dans un lien étroit avec les cadres administratifs du pouvoir séculier.

La situation évolua à partir de la fin du XIV ${ }^{\mathrm{e}}$ siècle, en raison de deux facteurs concomitants. Tout d'abord, les territoires occidentaux de l'ancienne Rus' correspondant aux limites de la future métropolie ruthène de Kiev - passèrent alors sous l'autorité des souverains polonais et lituaniens. Ces derniers devinrent de fait les patrons d'une Église dont ils n'étaient pas membres et qui, dans le sens juridique, occupa désormais une place secondaire dans les hiérarchies politiques et sociales en place. Cet aspect singulier représentait l'une des différences importantes par rapport au territoire moscovite et favorisa indirectement les tendances centrifuges à l'intérieur des structures ecclésiastiques kiéviennes. En effet, les nouveaux besoins financiers de la monarchie accélèrent le processus de distribution des terres au profit des seigneurs, pour récompenser leur service, et entraînèrent le passage de nombreuses églises sous le régime du patronage privé de la noblesse ${ }^{46}$. Dans les villes situées sur le domaine royal ou grand-princier, la concession d'autonomies municipales, d'après le modèle du droit de Magdebourg, avait également transféré l'exercice réel du droit de patronage sur les lieux de culte urbains à la municipalité et parfois même aux associations laïques locales ${ }^{47}$. Vers la fin du XVI ${ }^{\mathrm{e}}$ siècle, la majorité des églises ruthènes se trouvait déjà sous la tutelle des patrons « privés » et souvent non-orthodoxes (nobles, grands propriétaires ecclésiastiques ou communautés urbaines $)^{48}$. Si un tel émiettement du droit de patronage favorisa de nouvelles fondations au profit des sanctuaires, par la volonté des propriétaires de marquer de leur empreinte leurs nouveaux territoires, il plaça les desservants dans une étroite dépendance vis-à-vis des patrons. Dans le même temps, le poids des intérêts économiques permettait d'atténuer les différences confessionnelles dans les rapports entre les patrons et leurs dépendants, dont ils veillaient à éviter l'hostilité. Une illustration en est donnée, vers 1539, par

appel au terme allemand Eigenkirchenwesen ou « le régime d'églises privées » (Стефанович, Приход и приходское духовенство, p. 33-42).

46. Б.Н. Флоря, Исследования по истории Церкви. Древнерусское и славянское Средневековье Исследования по истории Церкви. Древнерусское и славянское Средневековье [Recherches sur l'histoire de l'Église. Le Moyen Âge chez les Slaves et dans l'Ancienne Rus'], M. : CNC «Pravoslavnaja enciklopedija», 2007, p. 103-104.

47. Voir Л.В. Тимошенко, « Парафіальне і братське самоврядування київської митрополії в добу Берестейської унії (друга половина XVI-XVII ст.) [L.V. Timošenko, L'autonomie des paroisses et des confréries de la métropolie de Kiev à l'époque de l'Union de Brest (seconde moitié du XVI ${ }^{\mathrm{e}}-\mathrm{XVII}^{\mathrm{e}}$ siècle)] », in H. Gmiterek, J. Łosowski, éd., Urzędy państwowe, organy samorządowe i kościelne oraz ich kancelarie [Les insitutions étatiques, les organes de gouvernement autonomes et ecclésiastiques, ainsi que leurs chancelleries], Cracovie : Avalon, 2010, p. 321-345.

48. М.Г. Долгая, « Некоторые аспекты правового регулирования имущественного положения православной церкви в Великом Княжестве Литовском до сер. XVII в. [M.G. Dolgaja, Quelques aspects de la régulation juridique de la situation foncière de l'Église orthodoxe dans la grande-principauté de Lituanie jusqu'au milieu du XVII ${ }^{\mathrm{e}}$ siècle] », Христианское чтение, 39 (4), 2011, р. 108-148. 
l'évêque latin de Vilnius, Paweł Holszański, qui fonda une église orthodoxe dans sa propriété de Hudzevičy (à l'est de Hrodna) ${ }^{49}$.

Le problème ne fut pas tant l'existence même du droit de patronage que son exercice abusif dans le cas des structures ruthènes ${ }^{50}$. Dans l'Église catholique latine, les réformes menées depuis le $\mathrm{XII}^{\mathrm{e}}$ siècle aboutirent à une réduction des prérogatives des fondateurs laïcs à la possibilité de présenter le candidat de leur choix à la cure vacante et à la perte, du moins en théorie, du droit de propriété sur les bénéfices ecclésiastiques ${ }^{51}$. Dans l'Église ruthène, et en suivant le modèle byzantin, les patrons avaient continué à administrer les biens des églises dont ils devaient en principe assurer la sauvegarde. En effet, ils n'hésitaient pas à considérer les sanctuaires et leurs terres comme leurs possessions propres, qu'ils faisaient fréquemment figurer sur les inventaires de leurs domaines au point d'entraîner des situations incongrues ${ }^{52}$. En janvier 1604, le droit de patronage sur l'église ruthène de Berestavica (district de Hrodna) fut ainsi divisé entre, d'une part, Andrzej Leszczyński et Janusz Zasławski, qui représentaient leurs épouses défuntes - toutes les deux filles de l'hetman Roman Sanguszko - et, de l'autre, le prince Teodor (Fedor) Massalski ${ }^{53}$. Puisque le domaine devait être divisé en deux parts égales, il en fut de même avec l'église dont les biens furent partagés de part et d'autre d'une ligne imaginaire, tracée depuis l'entrée jusqu'à l'autel. Chacun des nouveaux patrons se vit attribuer la propriété de quatorze icônes accrochées dans le sanctuaire et les trois cloches furent réparties en fonction de leurs tailles respectives.

Les prêtres se retrouvaient ainsi dans une stricte dépendance économique des patrons. Ce qui pouvait relever d'une simple formalité pour les familles cléricales aisées et les paroisses situées dans les propriétés royales devenait parfois un véritable outil de pression fiscale entre les mains des patrons laïcs sur les domaines privés. Avant d'être consacré par l'évêque, le candidat devait obtenir la lettre de « présentation » (презента/prezenta), adressée au hiérarque par le patron au nom $\mathrm{du}$ ius collationis. Certains d'entre eux tiraient alors profit de cette position de force pour exiger du postulant une rétribution pécuniaire en échange du document. Les futurs prêtres qui ne disposaient pas d'économies suffisantes devaient donc s'engager à rembourser les sommes réclamées par le patron, une fois entrés en possession du bénéfice. En 1647, la Diète reconfirma expressément ce droit et il fut interdit

49. NIAB (Национальный Исторический Архив Беларуси - Archives historiques nationales du Bélarus), f. 1774, op. 1, d. 3, 1. 989 r ; Aкты, издаваемые, t. 33, Vilnius, 1908, p. 218-219.

50. En effet, cette même institution concernait tout autant le clergé latin et, encore au $\mathrm{XVIII}^{\mathrm{e}}$ siècle, près de $57 \%$ des paroisses polono-lituaniennes relevaient du ius patronatus de la noblesse (Litak, Parafie w Rzeczypospolitej, p. 99).

51. G. Huard, «Considérations sur l'histoire de la paroisse rurale, des origines à la fin du Moyen Âge », RHEF, 102 (1938), p. 12-13 ; B. Szady, Prawo patronatu w Rzeczypospolitej w czasach nowożytnych [Le droit de patronage dans la République polono-lituanienne à l'époque moderne], Lublin : Liber, 2003, p. 6-7, 29-34.

52. Флоря, Исследования по истории Церкви, р. 59-60.

53. Акты, издаваемые, t. 1, Vilnius, $1865, \mathrm{n}^{\circ} 4$, p. 16-21. 
à l'épiscopat ruthène de s'immiscer dans les choix des collateurs, ne leur laissant que le droit d'instituer canoniquement les personnes ainsi désignées ${ }^{54}$. Une telle habitude encourageait naturellement les desservants à faire payer les sacrements qu'ils administraient aux paroissiens. À la fin du $\mathrm{XVI}^{\mathrm{e}}$ siècle, ces deux pratiques complémentaires, vues comme des abus par les Latins, étaient déjà devenues une véritable coutume dans l'ensemble de la métropolie de Kiev.

Cette situation s'expliquait non seulement par l'application du ius patronatus, mais aussi par les dispositions énoncées dans la Confédération de Varsovie de janvier 1573. Cet acte, qui devait être confirmé à chaque nouvelle élection royale, interdisait aux pouvoirs laïcs (et à plus forte raison ecclésiastiques) d'intervenir sur les propriétés d'un noble au nom de motifs religieux. Sur ses domaines, un seigneur était donc libre de disposer des églises et des biens qui leur étaient associés. De cette manière, les prêtres devenaient une sorte de clients et s'intégraient dans les réseaux personnels, constitués autour de grands seigneurs. Le clientélisme était d'autant plus visible dans les structures de rite grec, que les nouveaux prêtres étaient souvent les enfants ou les proches parents du précédent et leur bénéfice constituait pour eux une forme de patrimoine familial. De même, la dépendance se révélait encore plus étroite pour le clergé paroissial hostile à l'Union, car, après avoir perdu sa légitimité aux yeux du pouvoir royal, il fut obligé de s'abriter derrière la protection seigneuriale pour exercer sa charge pastorale ${ }^{55}$.

Cette position chancelante constitue vraisemblablement l'une des raisons pour lesquelles les paroisses de rite grec polono-lituaniennes eurent tendance à se définir surtout comme une communauté de fidèles et beaucoup moins comme une circonscription territoriale aux frontières bien établies. Un reflet de cette particularité se trouve peut-être dans le vocabulaire même qui fut employé pour désigner la paroisse. Aux $\mathrm{XII}^{\mathrm{e}}-\mathrm{XIII}^{\mathrm{e}}$ siècles, cette dernière correspondait aux circonscriptions séculières appelées yrззд (équivalent d'une viguerie ou d'une prévôté), mais fut également désignée par le terme $n р е \partial r \_\pi^{56}$. À partir des dernières décennies du $\mathrm{XV}^{\mathrm{e}}$ siècle, et avec les progrès de l'évangélisation, la terminologie adopta le mot приход (du verbe приходити : venir) devenu courant dans la métropolie de Kiev vers la fin du $\mathrm{XVI}^{\mathrm{e}}$ siècle $^{57}$. C'est alors que, sous influence latine, l'Église ruthène

54. Volumina LEGUM. Przedruk zbioru praw staraniem XX. Pijarów w Warszawie od roku 1732 do roku 1782 wydanego [Volumina LEGUM. Réimpression du recueil des lois, publié à Varsovie entre l'année 1732 et l'année 1782 par les pères piaristes], t. 4, SPb. : Jozafat Ohryzki, 1860 , p. 59.

55. Le prêtre de l'église Saint-Georges de Vilnius, Damian Dobryński, après avoir été chassé de la capitale lituanienne par le métropolite dès 1595, put ainsi trouver refuge à l'église de Hlybokae, sur la demande de Teodora Wołłowicz, épouse orthodoxe du voïvode de Brest Krzysztof Zenowicz qui possédait la partie occidentale de la bourgade (Акты, издаваемые, t. 33, p. 162-163).

56. Баловнев, « Приходское духовенство в Древней Руси... », р. 253 ; Скочиляс, Галищька (львівська) спарія, p. 477. Dans le diocèse de L'viv, l'usage du terme предъљ se maintint jusqu'au milieu du XVII siècle.

57. Стефанович, Приход, p. 239-241. Pour l'espace moscovite, la première attestation date de 1485 et concerne l'église de Perejaslavl' construite par le prince de Rjazan' Ivan Vasil'evič. ; Скочиляс, Галицька (львівська) єпарія, р. 477. 
adopta la désignation парафия (transposition du mot grec latinisé parochia, à travers la forme polonaise parafia) qui supplanta progressivement ses prédécesseurs. Cette évolution lexicale semble montrer qu'avec le recul du patronage princier, la paroisse fut comprise avant tout à travers le service cultuel qu'elle assurait auprès des fidèles et comme le lieu de leur rassemblement.

Pour autant, la construction d'un nouveau lieu de culte n'impliquait pas obligatoirement la naissance d'une nouvelle paroisse, au sens institutionnel étroit $\mathrm{du}$ terme, et il arrivait qu'un prêtre ait la charge de deux ou de plusieurs églises sur des territoires voisins. Tel était le cas de la fondation du voïvode de Vicebsk, Stanisław Kiszka, qui, en 1607, créa une nouvelle cure uniate dans sa propriété de Xowxlava, située sur la frontière des voïvodies de Vilnius et de Minsk ${ }^{58}$. Le futur desservant chargé des dépendants de Xowxlava, qui, « à cause de la ruine des églises ruthènes, vivaient depuis longtemps dans l'indécence et presque sans connaître Dieu », devait aussi assurer le service dans l'église de la bourgade voisine de Jarokgrodek (Haradok). Donc, dès sa refondation, la paroisse uniate disposait de deux centres distincts, séparés d'une dizaine de kilomètres. Vers 1680, les deux édifices continuaient à relever d'un seul et même prêtre ${ }^{59}$.

Contrairement à l'affirmation de certains auteurs, il paraît erroné de voir dans cette organisation une forme d'églises filiales d'après le modèle latin, car, à la différence de ce dernier, les documents n'évoquaient aucun lien de dépendance entre l'église-mère et les autres lieux de culte voisins ${ }^{60}$. Malgré le caractère succinct des chartes de fondation, chaque édifice cultuel ruthène paraissait disposer d'un statut équivalent. Rien n'indique, par exemple, pour les églises dévolues à un seul desservant, qu'une seule d'entre elles était réservée à des liturgies particulières ou à l'administration des sacrements aux paroissiens, y compris ceux du baptême ou du mariage. Seuls les prêtres étaient amenés à se déplacer, en fonction des dispositions prévues par les fondateurs. De fait, les patrons semblaient être les principaux acteurs de l'organisation locale du réseau paroissial selon l'étendue de leurs propriétés, la répartition confessionnelle ou le nombre de leurs dépendants, mais également de leur générosité envers l'Église. Cette influence pouvait aller jusqu'à tracer l'assise territoriale de la paroisse qui se confondait alors avec le domaine du fondateur. L'acte de fondation de l'église de Xowxlava précisait ainsi :

Pour le meilleur entretien du prêtre, qui doit également entretenir un diacre pour le chant et l'éducation des enfants, nous enregistrons et établissons à jamais la redevance suivante pour tous les dépendants de Xowxlava et de Jarokgrodek,

58. Описание рукописного отделения Виленской публичной библиотеки [Inventaire du département des manuscrits de la Bibliothèque publique de Vilnius], t. 3, Vilnius, $1898, \mathrm{n}^{\circ} 51$, p. 107-109.

59. Лісейчыкаў, éd., Візіты уніяцкіх ичэркваў, p. 38.

60. Ce terme est par exemple appliqué aux structures orthodoxes par Antoni Mironowicz (A. Mironowicz, Podlaskie ośrodki i organizacje prawosławne w XVI i XVII wieku [Les centres et les organisations orthodoxes de Podlachie aux XVI $\mathrm{XVVII}^{\mathrm{e}}$ siècles], Białystok : Archidiecezja Prawosławna Białostocko - Gdańska : Uniwersytet Warszawski Filia w Białymstoku, 1991, p. 74-75). 
et pour tous les dépendants de nos nobles et serviteurs chasés, qui relèvent de Xowxlava, sans exception aucune, à savoir qu'ils donnent chaque année au prêtre pour une wtóka [NdT : 21,36 hectares] en censive, qu'ils soient Lituaniens ou Ruthènes, et à la place de la dîme quatre gros lituaniens $[\ldots]^{61}$.

De telles indications ne signifiaient pas pour autant que l'aspect territorial des paroisses était déjà relativement stabilisé dès le début du XVII ${ }^{\mathrm{e}}$ siècle. D'ailleurs, la majorité des chartes de fondation parlait d' " églises » (cerkiew/ иерковь) et non de paroisses, tout en restant très laconiques sur les tracés exacts de leur cadre territorial $^{62}$. Un domaine pouvait être vendu ou divisé suite aux aléas des successions et ses nouveaux propriétaires pouvaient se montrer réticents à voir leurs dépendants payer des redevances au profit d'un prêtre qui relevait d'un seigneur voisin. Un conflit donne l'occasion d'illustrer la complexité des rapports entre les cadres du territoire ecclésiastique et les intérêts concurrents des laïcs. Il ressort d'une plainte, déposée le 20 octobre 1622, au tribunal territorial de Hrodna, par le prêtre de la paroisse uniate de Hudzevičy, déjà évoquée, contre Krzysztof Wiesiołowski. Ce dernier détenait la charge prestigieuse de maréchal curial de Lituanie, mais également celle d'intendant (ekonom) du domaine princier de Hrodna. L'ecclésiastique l'avait cité à comparaître à plusieurs reprises en raison des agissements de l'un de ses subordonnés, Jan Klukowski, le vice-staroste de la propriété de Krasniki. Selon le prêtre, cette localité, située à onze kilomètres à l'ouest de Hudzevičy, relevait depuis longtemps de son église. Cependant Klukowski interdisait aux habitants de Krasniki de se rendre à la messe dans l'église de Hudzevičy ou d'y recevoir les sacrements du baptême et du mariage ${ }^{63}$. Il est difficile d'estimer si ce conflit avait des motifs « confessionnels » ou si le vice-staroste s'appuyait sur ce prétexte pour soustraire ses paysans aux paiements des sommes destinées à l'Église. Néanmoins, l'intérêt principal de l'extrait réside dans les arguments du prêtre uniate. Celui-ci présenta une charte obtenue en 1620 de l'administration princière, qui lui confirmait l'ancienne fondation privée du $\mathrm{XVI}^{\mathrm{e}}$ siècle. Malheureusement pour le plaignant, le texte parlait bien de sa paroisse, mais ne mentionnait pas explicitement la localité de Krasniki. Ce document témoignait donc de l'imprécision et des ambiguïtés que pouvaient contenir les créations privées des paroisses ruthènes de cette époque, y compris quand - comme dans ce cas - le fondateur était lui-même un prélat.

Le desservant uniate dut s'appuyer alors sur l'argument de la coutume et attesta oralement que Krasniki relevait depuis longtemps de sa paroisse. Ensuite, il fit appel à la raison pratique " puisqu'il n'y avait aucune autre église plus proche de ladite propriété de Krasniki, à l'exception [de celle] de la religion saxonne et une schismatique à Alekšycy, et encore [elles se trouvaient] par-delà la rivière Veracejka ». Il termina son propos par un parallélisme avec les structures latines, vraisemblablement dans le but de clarifier la situation aux yeux des juges : « et

61. Описание рукописного отделения, t. 3, n 51, p. 108.

62. Скочиляс, Галицька (львівська) спарія, р. 478.

63. Акты, издаваемые, t. 33, р. 218-219. 
cette église de Hudzevičy se tient ainsi comme une filiale (филяй) au milieu de sa propre paroisse et afin qu'il n'y ait plus de telle licence ecclésiastique, il demanda, de lui attribuer ladite paroisse (парафия) ». La formule laissait supposer que les terres rattachées à l'église se trouvaient entièrement ou en partie sur le territoire du domaine de Krasniki et que le prêtre en était donc dépossédé. La plainte fut finalement renvoyée par le tribunal territorial devant les instances royales, puisqu'elle concernait le domaine princier. La suite de l'affaire demeure inconnue, mais le conflit paraît avoir duré encore une vingtaine d'années, car en 1641 Ladislas IV dut confirmer l'attribution de deux włóki de terre afin de pourvoir à l'entretien de l'église et de son clergé ${ }^{64}$.

L'exemple de Hudzevičy offre diverses pistes de lecture pour l'étude du réseau paroissial ruthène du début du XVII ${ }^{\mathrm{e}}$ siècle. La confusion entre le droit de propriété et le droit de patronage dans l'Église orientale laissait aux fondateurs la possibilité de maintenir dans le flou les délimitations précises des paroisses qu'ils créaient. Si cela leur donnait davantage de souplesse dans la gestion future de leurs biens fonciers, cette pratique pouvait aussi engendrer des litiges et des tensions, quand le domaine changeait de propriétaire ou était partagé entre les héritiers. À partir de la fin $\mathrm{du} \mathrm{XVI}^{\mathrm{e}}$ siècle, les processus réformateurs, nés dans la métropolie de Kiev, mais également l'influence de l'exemple latin, comme le révèlent les évolutions $\mathrm{du}$ vocabulaire, poussèrent les clercs ruthènes à vouloir donner une définition géographique plus nette à leur ministère. L'objectif premier était de stabiliser territorialement la communauté des fidèles, liée à un édifice, afin de garantir les revenus des paroisses, malgré le choix officieux entre l'adhésion ou la résistance à l'Union, qui s'offrait aux fidèles de l'Église kiévienne. En absence de preuves juridiques suffisantes, les frontières paroissiales émergèrent progressivement à travers la coutume fondée sur le recours régulier aux services cultuels d'une église et de son clergé 65 .

Quand le regard s'écarte de la représentation institutionnelle, tracée par les canons conciliaires du premier millénaire chrétien, pour plonger dans la réalité sociale de la période moderne, l'image de la paroisse devient à la fois plus concrète et plus éphémère. La place très réduite de la rhétorique confessionnelle dans l'abondante documentation foncière relative aux églises ruthènes témoigne qu'encore au XVII ${ }^{\mathrm{e}}$ siècle, uniates et orthodoxes se confrontaient à des défis structurels similaires. La paroisse se révèle alors comme un point d'attraction cultuelle et fiscale à l'intérieur d'une assemblée de croyants réunie par des liens étroits de nature géographique et religieuse, mais également juridique, économique ou professionnelle.

64. NIAB, f. 1774, op. 1, d. 3, 1. 989r.

65. Le XVII ${ }^{\mathrm{e}}$ canon du concile œcuménique de Chalcédoine (451) reconnaissait ainsi aux évêques la " possession» de droit d'une paroisse, s'ils l'avaient administrée de manière régulière durant une période de trente ans. 


\section{Les confréries : vers l'émergence d'un modèle orthodoxe ruthène}

Les nombreux défis institutionnels posés à l'Église kiévienne par son statut de minorité religieuse et par la faiblesse de l'encadrement paroissial produisirent dès la seconde moitié du $\mathrm{XVI}^{\mathrm{e}}$ siècle des initiatives réformatrices parfois contraires. Les métropolites et quelques évêques ruthènes tentèrent de freiner les mouvements centrifuges du clergé par une mise en avant des hiérarchies intermédiaires autour des vicaires (намъстники) et des archiprêtres (npoтоnоnь) — charges qui furent de plus en plus souvent cumulées par les mêmes individus - censés incarner localement l'autorité épiscopale à la fois dans les domaines temporel et spirituel. Dans le même temps, ces évolutions institutionnelles encore balbutiantes et réduites aux centres principaux du diocèse métropolitain, laissèrent la place nécessaire à l'émergence de courants réformateurs venus d'en bas et nés dans les diocèses méridionaux de la Couronne, là où le contrôle métropolitain était le moins assuré et où le contact avec le monde latin était ancien et étroit. Dans les principales cités de ces régions, et en raison d'un rapport de force plus favorable aux catholiques, les Ruthènes avaient été mis à l'écart non seulement du gouvernement municipal, mais également des charges importantes dans les métiers ${ }^{66}$. Par conséquent, le cadre paroissial devint pour eux à la fois le marqueur de leur particularisme et la seule institution établie, capable de rassembler la communauté.

Malgré des démarcations très nettes face aux Latins, les premières formes de ces associations orthodoxes se construisirent dans un étroit mimétisme face à la confession dominante. Dès 1502, à L'viv, les membres de ces organisations paroissiales furent désignés dans les sources comme « vitrici ou prouisores ecclesiae », en transposant la terminologie qui qualifiait les fabriques dans l'Église latine ${ }^{67}$. À partir des années 1540 , ces termes commencèrent à être remplacés par ceux de conftratres et uicini patroni, donnant naissance aux premières formes de «confréries » religieuses orthodoxes avec un recrutement confessionnel qui découlait des rapports socioprofessionnels propres à ces régions ${ }^{68}$. Ailleurs, notamment en Lituanie, les laïcs jouaient également un rôle majeur dans le fonctionnement des paroisses, mais leurs actions s'inscrivaient ici dans des cadres parallèles, le plus souvent ceux de la

66. Le cas le mieux connu est celui de la cité de L'viv. Voir M. Капраль, Національні громади Львова XVI-XVIII cm. (соиіально-правові взаємини) [M. Kapral', Les communautés nationales de L'viv $\mathrm{XVI}^{\mathrm{e}}$-XVIII ${ }^{\mathrm{e}}$ siècles (relations socio-juridiques)], L'viv : Львівський національний університет ім. Івана Франка, Інститут української археографії та джерелознавства ім. М.С. Грушевського НАН України, 2003.

67. Ю.Э. Шустова, Документы львовского Успенского ставропигийского братства (1586-1788) [Ju.E. Šustova, Les documents de la confrérie stavropigiale de la Dormition de L'viv (1586-1788)], M. : Rukopisnye pamjatniki drevnej Rusi, 2009, p. 89.

68. À la différence des confréries de métiers et autres fraternités urbaines lituaniennes, les statuts de ces associations étaient confirmés par les évêques locaux et non par le prince ou la municipalité. 
municipalité, qui entendaient contrôler l'administration des biens ecclésiastiques ruthènes sur l'ensemble du territoire urbain ${ }^{69}$.

Si ces premières initiatives manquèrent de cohésion et furent largement dépendantes du contexte religieux local, le mouvement initié par les élites urbaines orthodoxes trouva son aboutissement quelques années plus tard avec les confréries religieuses créées ou réorganisées au début des années $1580^{70}$. Les plus importantes d'entre elles furent la confrérie formée autour de l'église de la Dormition à L'viv et celle constituée à Vilnius auprès de l'église monastique de la Sainte-Trinité, avant d'être transférée, en 1597, vers la nouvelle église orthodoxe du Saint-Esprit ${ }^{71}$. Le statut de ces associations fut renforcé par le soutien reçu des patriarches constantinopolitains qui, en 1592, accordèrent à la confrérie de la Dormition de L'viv un privilège d'exemption ( $\sigma \tau \alpha v \rho o \pi \eta ́ \gamma ı \alpha$ - stavropêgía), qui la soustrayait à la juridiction de l'évêque local et même à celle du métropolite de $\mathrm{Kiev}^{72}$. Le prestige acquis rapidement par la confrérie de L'viv entraîna la diffusion de ce modèle dans d'autres villes et bourgades voisines, qui reproduisaient de manière assez proche ses statuts, et la formation d'un réseau qui, par ses pratiques, rappelait les archiconfréries occidentales. Prenant appui sur les structures paroissiales, les principales confréries ruthènes entendaient exercer localement des fonctions normalement dévolues à l'évêque ou à ses représentants (en particulier, dans l'organisation du travail pastoral et dans le contrôle de la discipline ecclésiastique), à l'exception de la liturgie et de l'administration des sacrements ${ }^{73}$. Dans l'émulation qui précéda l'Union de Brest, certaines paroisses ruthènes des cités importantes n'étaient donc

69. Ces agissements débouchaient fréquemment sur des frictions avec l'épiscopat, comme en témoigne le conflit survenu dès 1511 à Vilnius entre le métropolite de Kiev Iosyf Soltan et les élites orthodoxes de la ville : Археографический сборник документов, относящихся к истории Северо-Западной Руси [Recueil archéographique des documents relatifs à l'histoire de la Rus' du nord-ouest], t. 6, Vilnius, 1883, n 4, p. 5-12.

70. Sur cette thématique, les principales analyses sont dues à Jaroslav Isaevyč, notamment la version anglaise révisée de son travail pionnier de 1966 : I. Isaievych, The voluntary brotherhood: Confraternities of Laymen in Early Modern Ukraine, Edmonton : Canadian Institute of Ukrainian Studies, 2006. Une synthèse sur les origines de ce phénomène est présentée dans : С.С. Лукашова, Миряне и Церковь : религиозные братства киевской митрополии в конце ХVI века [S.S. Lukašova, Les laïcs et l'Église : les confréries religieuses de la métropolie de Kiev à la fin du XVI ${ }^{\mathrm{e}}$ siècle], M. : Institut slavjanovedenija RAN, 2006.

71. T. Kempa, «Wileńskie bractwo Św. Ducha jako centrum obrony prawosławia w Wielkim Księstwie Litewskim w końcu XVI i w pierwszej połowie XVII w. » [La confrérie du Saint-Esprit de Vilnius, comme centre de défense de l'orthodoxie dans la grande-principauté de Lituanie à la fin du XVI ${ }^{\mathrm{e}}$ et au début du XVII ${ }^{\mathrm{e}}$ siècle], Białoruskie Zeszyty Historyczne, 21, 2004, p. 47-69.

72. М. Капраль, éd., Привілеї національних громад міста Львова (хIVе-XVIII ст.) [M. Kapral', éd., Les privilèges des communautés nationales de la ville de L'viv (XIV'-XVIII ${ }^{\mathrm{e}}$ siècles)], L'viv : L'vivs'kij nacional'nij universitet im. I. Franka/ L'vivsk'ke viddilennja Institutu ukraïns'koï arheografiï ta džreloznavstva im. M. Gruševs'kogo NAN Ukraïni, 2010 [2 édition], $\mathrm{n}^{\circ} 7$ (176), p. 517-520.

73. Sur le programme religieux développé par ces associations voir : M.V. Dmitriev, « Les confréries de Ruthénie dans la deuxième moitié du XVI siècle - une "Réforme orthodoxe"? ", in M. Derwich, M.V. Dmitriev, éds., Être catholique - être orthodoxe-être protestant : confessions et identités culturelles en Europe médiévale et moderne, Wrocław : LARHCOR, 2003, p. 208-220. 
plus un simple cadre institutionnel et social de la communauté orthodoxe, mais cherchaient à devenir un lieu de gouvernement ecclésiastique bien au-delà de leurs limites territoriales.

Parmi leurs différentes activités, les confréries ruthènes accordaient une attention particulière à l'éducation et, dès les années 1590, celles de L'viv et de Vilnius disposaient d'écoles dont les programmes se rapprochaient des modèles des collèges catholiques, avec un enseignement du grec, du latin et du slavon ${ }^{74}$. En devenant les acteurs du renouveau culturel kiévien des dernières décennies du XVI ${ }^{\mathrm{e}}$ siècle, les associations orthodoxes offrirent également une tribune aux nouveaux courants spirituels locaux et aux enseignements des ecclésiastiques venus des territoires helléniques à l'invitation des confrères ${ }^{75}$.

En effet, la diffusion d'une littérature de prédication connue dans l'historiographie sous le terme d'Évangiles commentés (Учительные Евангелия) « de nouveau type » se fit à l'intérieur et à destination des structures paroissiales. Ces textes, qui apparurent dans les années 1560, puisaient aux divers modèles confessionnels pour alimenter une religion plus vivante et une piété plus intériorisée chez les fidèles ${ }^{76}$. Leur intention était de servir de recueil pratique aux prêtres orthodoxes pour les aider à préparer des prêches en langue vernaculaire, capables de répondre aux attentes de leurs ouailles. La zone d'apparition de ces ouvrages correspondait précisément à la voïvodie de Ruthénie, qui vit se développer quelques années auparavant les principales confréries religieuses orthodoxes. Même si les sources conservées ne fournissent aucune donnée précise pour établir un lien direct entre les prêtres, auteurs anonymes de ces textes, et les associations religieuses ruthènes, ce parallélisme suggère que les confréries jouèrent avec l'aide de clercs lettrés un rôle dans la diffusion de la nouvelle spiritualité auprès des chrétiens orientaux de la République.

74. К.В. Харлампович, Западнорусские православные школы хVI и начала хVII века [K.V. Harlampovič, Les écoles orthodoxes de la Rus' occidentale au XVI et au début du XVII ${ }^{\mathrm{e}}$ siècle], Kazan' : Tipografija Imperatorskago Universiteta,1898 ; Шустова, Документы, p. 159-194.

75. Certains hiérarques grecs intervenaient même directement dans les conflits locaux pour dénoncer les erreurs rituelles des évêques ruthènes. Dès le mois de mai 1586, l'évêque Théophanès de Durrës et l'archevêque Arsenios d'Elassona, établis à L'viv, écrivirent à l'évêque local, Gedeon Bałaban, au sujet d'un conflit qui l'opposait aux confrères pour rappeler les règles rituelles qui condamnaient ces pratiques (А.С. Крыловский, Львовское ставропигиальное братство : опыт иерковно-исторического исследования [A.S. Krylovskij, La confrérie stavropigiale de L'viv : expérience d'une recherche en histoire ecclésiastique], Kiev : Tip. Imperatorskago Universiteta Svjatogo Vladimira, 1904, Annexes, ${ }^{\circ} 2$ 2, p. 14-15).

76. J. Janów, « Tłumaczenia ruskie z "Postylli” M. Reja w ewangeliarzach kaznodziejskich XVI i XVII w. [Les traductions ruthènes du Postylla de Mikołaj Rej dans les Évangiles commentés des $\mathrm{XVI}^{\mathrm{e}}$ et XVII ${ }^{\mathrm{e}}$ siècles ]», Sprawozdania z czynności i posiedzeń Polskiej Akademii Umiejętności, 34 (8), 1929, p. 2-10 ; Г. Чуба, « Текстологічне дослідження українських учительних Свангелій другої половини XVI-початку XVII ст. : перемишльський тип » [H. Čuba, Examen textologique des Évangiles commentés ukrainiens de la seconde moitié du $\mathrm{XVI}^{\mathrm{e}}$ et du début du XVII ${ }^{\mathrm{e}}$ siècle : le type de Przemyśl], Вісник Львівського університету. Книгознавство, бібліотекозпавство та інформаційні технології, 2, 2007, p. 5-38. Voir également le récent inventaire de ces ouvrages : Г. Чуба, Украӥнські рукописні учительні Євангелія : дослідження, каталог, описи [H. Čuba, Les Évangiles commentés manuscrits d'Ukraine : analyse, catalogue, description], L'viv - Kiev : Kievo-Mogil. Akad.-Svičado, 2011. 
De la même façon, les ecclésiastiques liés au monde des confréries servirent d'agents dans les tentatives de réforme des pratiques liturgiques ruthènes d'après les normes venues du monde grec. En automne 1592, l'arrivée dans la confrérie de la Sainte-Trinité de Vilnius de deux prêtres et d'un diacre, chassés du diocèse de L'viv en raison de conflits avec l'évêque local, déboucha sur l'introduction de nouvelles cérémonies dans l'administration de certains sacrements, à la grande « surprise » (подивленье) des fidèles ${ }^{77}$. Celles-ci correspondaient notamment à la suppression de l'eucharistie dans le rite du mariage, une évolution qui commençait précisément à apparaître dans certains eucologes grecs du XVI ${ }^{\mathrm{e}}$ siècle $^{78}$. Cet indice laisse donc penser que ces transformations liturgiques s'inscrivaient plus ou moins directement dans les influences exercées par les Grecs dans les confréries ruthènes du diocèse de L'viv.

L'ensemble des activités menées par les confréries et leurs aspirations à l'autonomie débouchèrent progressivement sur une confrontation avec la hiérarchie ecclésiastique orthodoxe. En effet, malgré l'engagement de plusieurs évêques kiéviens dans la réforme locale de l'Église, comme l'énonçaient les synodes métropolitains des années 1590, le clergé entendait conserver une autorité exclusive et incontestée dans ce mouvement ${ }^{79}$. Si ces tensions furent incontestablement l'un des facteurs de l'Union et du schisme qui s'ensuivit, l'expérience et le rayonnement acquis par les confréries permirent aux structures paroissiales orthodoxes de se maintenir malgré la disparition de la plus grande partie de leurs supérieurs. Dans certaines régions, l'Église orthodoxe se trouva réduite aux seules structures paroissiales, qui tentèrent alors de remplacer l'organisation hiérarchique du clergé par des réseaux noués entre les paroisses les plus actives, structurées autour des monastères et pourvues de confréries. Dans la partie lituanienne du diocèse métropolitain, seuls les archiprêtres de Zabłudów et de Sluck choisirent de demeurer dans l'obédience de Constantinople et purent exercer leur charge à la protection des grandes familles de la noblesse ${ }^{80}$. Devant ce vide institutionnel, le monastère du Saint-Esprit de Vilnius, soutenu par sa confrérie, devint dans les premières

77. Акты, относящиеся к истории Западной России [Actes relatifs à l'histoire de la Russie occidentale], t. 4, SPb., 1848, n 41, p. 59-61.

78. М.C. Желтов, « Венчание брака » [M.S. Želtov, La consécration du mariage], Православная энииклопедия, t. 7, p. 663-664.

79. М.В. Дмитриев, Между Римом и Царградом : генезис брестской иерковной унии, 1595-1596 zz. [M.V. Dmitriev, Entre Rome et Constantinople : la genèse de l'Union ecclésiastique de Brest, 1595-1596], M. : MGU, 2003, p. 89-132 ; Л.В. Тимошенко, « Ставропігія церковних братств і генеза Берестейської унії » [L.V. Timošenko, La stavropigie des confréries religieuses et la génèse de l'Union de Brest], in A. Gil, éd., Koøcioły wschodnie w Rzeczypospolitej XVI-XVIII wieku : zbiór studiów [Les Églises orientales dans la République polono-lituanienne aux XVI ${ }^{\mathrm{e}}$-XVIII ${ }^{\mathrm{e}}$ siècles : recueil d'études], Lublin : IEŚW, 2005, p. 234-250.

80. W. Milkowicz, éd., Monumenta confraternitatis stavropigianae Leopoliensis, t. 1, L'viv : Institutus Stavropigianus, 1895, n 435, p. 753 ; R. Degiel, Protestanci i prawostawni : patronat wyznaniowy Radziwiłlów birzańskich nad Cerkwia prawosławna w księstwie stuckim w XVII w. [Protestants et orthodoxes : le patronage confessionel des Radziwiłł, de la branche de Biržai, sur l'Église orthodoxe dans la principauté de Sluck au XVII ${ }^{\mathrm{e}}$ siècle], Varsovie : Neriton, 2000, p. $73-78$. 
décennies du $\mathrm{XVII}^{\mathrm{e}}$ siècle une véritable institution de gouvernement qui, vers 1650, exerçait une tutelle sur treize autres monastères et plusieurs églises, répartis à travers l'espace de la grande-principauté de Lituanie ${ }^{81}$. Tout naturellement, de telles évolutions ne concernaient que les villes dotées d'une communauté ruthène importante et attentive aux débats suscités par la nouvelle pastorale orthodoxe et par l'Union. Il serait donc légitime de supposer que la majorité des paroisses, mêmes celles dont le prêtre énonçait explicitement sa fidélité au patriarcat de Constantinople, ne subirent aucune modification profonde dans leur fonctionnement interne. Pour autant, l'organisation en confrérie devint incontestablement un modèle pour les communautés paroissiales orthodoxes, comme en témoigne leur apparition après 1596 dans les capitales diocésaines (à Kiev en 1615 ou à Luc'k en 1617), pour pallier la perte des évêques devenus uniates, mais aussi dans d'autres centres locaux comme à Minsk en $1612^{82}$. Pour autant, les associations de fidèles ruthènes n'étaient pas un phénomène exclusivement orthodoxe, car l'Église uniate possédait aussi des confréries, dont la plus célèbre s'était formée auprès du monastère de la Sainte-Trinité de Vilnius, après le départ des orthodoxes vers leur nouvelle église du Saint-Esprit. Néanmoins, ces organisations restèrent sous le contrôle étroit de l'épiscopat d'après le modèle latin, qui fut progressivement assimilé par ces organisations.

En revanche, la liberté obtenue de fait par le mouvement confraternel orthodoxe, après l'effacement de la tutelle de l'épiscopat rallié à l'Union, l'amena à vouloir consolider son statut par des privilèges ecclésiastiques directement accordés par les patriarches orthodoxes. Au cours du séjour de Théophane de Jérusalem dans la République et au moment même du rétablissement de nouveaux évêques orthodoxes à Kiev, même s'ils ne furent pas reconnus par le roi, au moins trois confréries sollicitèrent avec succès le patriarche afin d'obtenir à leur tour un privilège d'exemption (stavropigie $^{83}$. À terme, la consolidation des autonomies confraternelles créa inévitablement des heurts avec la nouvelle hiérarchie cléricale. Dès 1626, à la demande de l'archevêque de Polack Melecjusz Smotrycki, qui se rattachait encore au camp orthodoxe, le patriarche de Constantinople Cyrille Lukaris accepta de replacer les confréries stavropigiales dans l'obédience des diocésains locaux, avec une seule exception pour celles de L'viv et de Vilnius ${ }^{84}$. Toutefois, l'enracinement de ces institutions dans la vie des communautés orthodoxes kiéviennes fit longtemps tergiverser la hiérarchie ecclésiastique sur les actions à mener. Encore en 1633, le même patriarche Lukaris n'hésita pas à élargir le droit d'exemption à la confrérie

81. Voir le cas de l'église de Padarosk (au sud de Hrodna) : LMAB [Lietuvos Mokslu Akademijos Biblioteka - Bibliothèque de l'Académie des Sciences de Lituanie], Département des manuscrits, f. 264, $\mathrm{n}^{\circ} 1148$.

82. Il faut toutefois penser que l'affirmation du rôle des confréries n'était pas une simple conséquence du vide du pouvoir épiscopal, car la confrérie de L'viv resta très active après 1596 , alors même que l'évêque Bałaban avait rejeté le ralliement à Rome et s'était réconcilié avec l'association orthodoxe de sa cité.

83. Chodynicki, Kościól prawosławny, p. 425.

84. Голубев, Киевский митрополит, t. 1, n 66, p. 287-290. 
de Mahilew ${ }^{85}$. De fait, la plupart des confréries qui avaient reçu le privilège d'exemption continuèrent à le mentionner dans leur documentation encore dans les années $1680^{86}$.

La division de ces sociabilités constitua un processus long et non linéaire, car l'institution paroissiale était à la fois le lieu d'expression des frontières confessionnelles et un espace que la communauté considérait comme sien par-delà la démarcation religieuse. Une illustration de cette dualité se dessine dans une affaire survenue en 1621 entre l'archevêque uniate de Polack Jozafat Kuncewicz et un habitant de la ville Piotr Wasiliewicz ${ }^{87}$. Ce dernier était accusé d'avoir enterré lui-même dans le cimetière de l'église de la Nativité le corps de son petit-fils mort en bas âge, sans en informer le clergé local. Kuncewicz aurait ordonné aux clercs de la paroisse d'exhumer le corps et de l'enterrer d'après « les usages chrétiens qui s'imposaient ». Le grand-père et le père de l'enfant, accompagnés de leurs serviteurs, chassèrent alors les ecclésiastiques et enterrèrent de nouveau la dépouille. La réponse donnée par Wasiliewicz aux enquêteurs expliquait qu'il était orthodoxe et refusait que la messe funèbre de son descendant fût célébrée par un prêtre uniate. Surtout, ses propos exprimaient explicitement le refus d'accorder aux clercs l'autorité exclusive sur ce lieu sacré : « le terrain et le cimetière relèvent de Dieu et du Roi, et c'est nous qui avons construit l'église, nous avons donc le droit d'y enterrer les corps des défunts ». À l'intérieur des frictions entre uniates et orthodoxes, qui façonnaient des imaginaires repris et assimilés par les fidèles des deux obédiences, la paroisse restait encore une institution éminemment sociale, dont la sacralité se maintenait bien moins par l'exercice d'une juridiction ecclésiastique que par la mémoire de la communauté.

\section{L'Hetmanat cosaque et l'institutionnalisation au service de la différenciation}

Malgré la diminution du rôle assigné aux structures confraternelles, après 1633 et le rétablissement de la hiérarchie épiscopale orthodoxe, les modèles organisationnels développés par les opposants à l'Union au cours du premier $\mathrm{XVII}^{\mathrm{e}}$ siècle marquèrent profondément les pratiques du gouvernement ecclésiastique. Cette influence fut particulièrement visible sur le territoire administré par les cosaques. En premier lieu, l'élite zaporogue assura une forte promotion des institutions monastiques, qui récupérèrent un nombre important des propriétés seigneuriales et prirent peu à peu la place économique des anciens magnats ${ }^{88}$.

85. Археографический сборник, t. 2, n 35, p. 47-48.

86. Degiel, Protestanci, p. 80-81.

87. Археографический сборник, t. 1, nº88, p. 263-264.

88. В.В. Панашенко, Соціальна еліта гетьманщини (друга половина хVII - хVIII ст.) [V.V. Panašenko, L'élite sociale de l'Hetmanat (seconde moitié du XVII ${ }^{\mathrm{e}}$ siècle-XVIII ${ }^{\mathrm{e}}$ siècle)], Kiev : Institut istoriï Ukraïni NAN Ukraïni, 1995, p. 24-27. 
Dans une moindre mesure, l'accroissement des propriétés ecclésiastiques profita également au clergé séculier, comme en témoigne l'universal de l'hetman Ivan Bruhovec'kyj, daté de 1664, qui confirmait au prêtre de la paroisse rurale de Vybli (dans le district de Černihiv), Ivan Avramovyč, l'usage du lac voisin de Nedan ${ }^{\prime 9}$. Ce soutien apporté aux sanctuaires paroissiaux provenait aussi des représentants locaux de l'hetman et, notamment, des colonels qui assuraient les fonctions militaires et administratives dans les nouveaux districts organisés à partir des régiments cosaques. En 1666, le colonel de Kiev, Vasyl' Dvorec'kyj, accordait ainsi à l'église Saint-Basile-de Césarée, situé dans un village voisin de la capitale, plusieurs terrains avec des ruches afin qu'elle en tire des revenus ${ }^{90}$. De même, les colonels transféraient souvent aux églises les revenus produits par les prélèvements locaux (douanes, taxes diverses, charroi, etc.) pour financer l'entretien et l'embellissement des lieux de culte ${ }^{91}$.

Nonobstant les nombreuses disparités locales, l'augmentation des revenus de l'Église orthodoxe placée sous l'autorité cosaque avait deux causes principales. Tout d'abord, elle tirait profit des profonds bouleversements dans la propriété foncière, qui avaient suivi l'insurrection de Bohdan Xmel'nyc'kyj. Cela renvoyait tout naturellement aux domaines abandonnés par la noblesse catholique, mais aussi aux anciennes propriétés des différentes institutions religieuses non-orthodoxes, qui avaient été chassées par les nouvelles autorités. Peu après la victoire cosaque de Zboriv du 17 août 1649, le document adressé à Jean II Casimir et intitulé les Points relatifs aux besoins de l'armée zaporogue, exigeait clairement d'enlever leurs bénéfices aux jésuites et aux autres ordres religieux à Kiev et dans les autres villes cosaques, de supprimer l'évêché latin de Kiev et d'interdire aux juifs, quel que fût leur métier, de s'établir et de circuler sur le territoire cosaque, à l'exception de brefs séjours pour le commerce ${ }^{92}$. Toutefois, l'attention principale du texte allait aux uniates qui, pourtant, étaient peu implantés dans les trois voïvodies qui devaient constituer l'Hetmanat. L'Union devait ainsi être abolie sur l'ensemble du territoire de la République et les bénéfices ecclésiastiques de rite grec transmis au clergé orthodoxe. Ces interdictions et restrictions imposées aux confessions non-orthodoxes furent répétées de manière régulière dans les décennies suivantes.

89. I. Бутич, В. Ринсевич, I. Тесленко, éds., Універсали украӥнських гетьманів від Івана Виговського до Івана Самойловича (1657-1687) [I. Butyč, V. Rynsevyč, I. Teslenko, éds., Les « universaux » des hetmans ukrainiens depuis Ivan Vyhovs'kyj jusqu'à Ivan Samojlovyč (1657-1687)], Kiev - L'viv : NTŠ, 2004, n² 217, p. 322-323.

90. Ibid., $\mathrm{n}^{\circ} 32$, p. 873-874.

91. Voir par exemple : Ibid., $\mathrm{n}^{\circ} 80,111$, p. 908, 931. L'administration cosaque n'hésitait pas en outre à stimuler les fondations privées. En 1684, le colonel du régiment de Poltava exempta l'habitant d'Ivončenci Ivan Mazur du paiement de toutes les redevances publiques puisqu'il avait promis de léguer l'ensemble de ses biens meubles et immeubles à l'église de sa localité, Ibid., $\mathrm{n}^{\circ}$ 91, p. 916.

92. І.П. Крип'якевич, І. Бутич, éds., Універсали Богдана Хмельницьького (1648-1657) [I.P. Kryp'jakevyč, I. Butyč, éd., Les « universaux » de Bohdan Xmel'nyc'kyj (1657-1687)], Kiev : Al'ternativi, $1998, n^{\circ} 5$, p. 52-56. 
En accédant au rang de religion officielle et largement majoritaire, l'Église orthodoxe de l'Hetmanat put étendre son emprise foncière mais aussi juridique, tout particulièrement dans les grandes cités marquées auparavant par le pluralisme. Par un universal daté du 12 mai 1660, le colonel de Kiev Dvorec'kyj, déjà mentionné, transférait à l'église Saint-Nicolas de Kiev des terrains urbains qui avaient appartenu aux couvents franciscain et jésuite locaux, mais aussi à la communauté arménienne établie dans la cité ${ }^{93}$. Ces nouveaux espaces devaient, entre autres, servir à accueillir de nouveaux cimetières pour les paroissiens orthodoxes.

L'autre facteur de croissance était la proximité qui existait entre le clergé et les nouvelles élites laïques. En effet, il n'était pas rare de voir des officiers cosaques, après avoir mené une carrière plus ou moins longue dans les institutions séculières, prendre l'habit monastique ou obtenir des charges dans le clergé séculier (comme archiprêtres ou simples prêtres). Cela concernait tout particulièrement des lettrés qui avaient pu travailler à la chancellerie, à l'image du greffier de Hadjač Stepan Mokrievyč, devenu en 1677 prêtre de l'église cathédrale de la Dormition à Perejaslav ${ }^{94}$. À l'inverse, il arrivait que des enfants ou des parents de prêtres exercent des charges administratives dans les structures cosaques. Dans la même région, au cours des années 1670, Artamon Butovyč, le fils de l'archiprêtre de Hadjač, servit pendant huit ans à la Grande Chancellerie militaire avant de se faire prêtre dans la ville de son père ${ }^{95}$. Ces phénomènes aboutissaient à l'existence de familles bien implantées à la fois dans le clergé et dans les hiérarchies administratives locales. Un tel entremêlement social favorisait d'autant plus les parcours croisés et garantissait le soutien apporté par les instances laïques à l'Église.

Ces nouveaux équilibres ne semblent pas avoir entraîné un véritable basculement des pratiques du clergé paroissial qui continuait à assimiler les revenus produits par les charges pastorales à une sorte de patrimoine familial qu'il fallait essayer de préserver à l'intérieur d'une même parentèle. Cependant, les restructurations foncières et l'organisation même du pouvoir zaporogue entraînèrent une nette transformation du droit patronage qui s'appliquait aux propriétés ecclésiastiques. La place du patronage privé, tel qu'il était pratiqué dans la République polono-lituanienne par les seigneurs terriens, connut un net recul au profit du contrôle exercé par l'hetman et ses représentants locaux, mais aussi par les monastères orthodoxes. Cette évolution se reflète d'ailleurs dans la terminologie employée dans les « universaux » cosaques édictés à partir des années 1660, puisque le mot ктитор, essentiellement employé dans la métropolie kiévienne du premier $\mathrm{XVII}^{\mathrm{e}}$ siècle avec le sens de « fondateur » ou de « patron », y apparaît le

93. Бутич, Ринсевич, Тесленко, éds., Універсали, nº 28, p. 870-871.

94. Панашенко, Соціальна еліта, р. 30-31.

95. В.Л. Модзалевский, Малороссійскій родословникъ [V.L. Modzalevskij, Le recueil généalogique de la Petite-Russie], t. 1, Kiev : tip. F.L. Fronckeviča, 1908, p. 148-149. Il est intéressant de remarquer que les deux fils d'Artamon, Ivan et Hryhorij, se tournèrent de nouveau vers la carrière administrative et militaire. 
plus souvent pour renvoyer aux marguilliers ${ }^{96}$ et donc aux paroissiens chargés du contrôle des biens des sanctuaires ${ }^{97}$.

La mise en avant de cette fonction doit se lire comme un héritage des actions menées par les confréries ruthènes d'avant la création de l'Hetmanat. La référence à ce modèle organisationnel était présente aussi dans d'autres pratiques propres aux structures paroissiales orthodoxes de l'État cosaque. En effet, l'affaiblissement du patronage privé avait débouché sur un plus grand contrôle des charges pastorales par la communauté des fidèles, avec la consolidation du principe de l'élection des desservants, allant jusqu'à examiner les compétences et les talents des candidats pour la rhétorique et le service liturgique. Par certains aspects, le fonctionnement du clergé séculier du territoire zaporogue rappelait les rapports qui, à l'origine, avaient pu exister à l'intérieur des principales confréries ruthènes (Vilnius, L'viv, Kiev, Luc'k etc.) entre leurs membres ecclésiastiques et les laïcs placés à la tête de ces associations.

Il s'agissait donc d'une tendance commune à l'ensemble de l'Église ruthène qui, face à la concurrence confessionnelle issue des Réformes et ravivée par les tensions entre uniates et orthodoxes, vit des initiatives réformatrices laïques prendre une place de plus en plus grande dans la vie religieuse locale. $\mathrm{Si}$, en raison du poids politique et social de la noblesse et d'un rapport de force de moins en moins favorable aux non-catholiques, ces élans furent progressivement freinés sur le territoire resté sous le contrôle polono-lituanien, ils purent trouver un mode d'expression nouveau sous l'autorité cosaque. De fait, en lien avec le mouvement confraternel, celle-ci s'était progressivement construite sur une rhétorique qui reliait étroitement les hiérarchies sociales aux appartenances religieuses ${ }^{98}$. C'est pourquoi les modes de gouvernement ecclésiastique local, instaurés sur le territoire de l'Hetmanat, semblèrent au départ mettre en œuvre le programme religieux énoncé par les associations laïques ruthènes un demi-siècle auparavant.

Néanmoins, le recours à un mode d'organisation destiné à défendre la cohésion et les privilèges d'une communauté minoritaire pour forger les cadres structurels d'une entité territoriale nouvelle entraîna indéniablement une « politisation » croissante du clergé orthodoxe local, y compris de ses hiérarchies intermédiaires ${ }^{99}$.

96. Cette fonction était plus généralement désignée sous le terme de starosta cerkovnyj, qui commence à être attesté sur l'espace polono-lituanien à partir des années 1630 (М.Ф. Владимирский-Буданов, « Церковныя имущества в юго-западной России XVI века » [M.F. Vladimirskij-Budanov, Les propriétés ecclésiastiques dans la Russie du sud-ouest au $\mathrm{XVI}^{\mathrm{e}}$ siècle], Архив Юго-Западной России, t. 8/4, Kiev : tip. S.V. Kul'ženko, p. 84-87).

97. Par exemple : Бутич, Ринсевич, Тесленко, éds., Універсали, n 55, 73, p. 891, 903. Il faut souligner que l'emploi du terme avec ce second sens n'apparaît pas dans les documents de Bohdan Xmel'nyc'kyj.

98. La place de la religion dans les aspirations sociales et politiques des cosaques est traitée dans : C. Плохій, Наливайкова віра : козацтво та релігія в ранньомодерній Украӥні [S. Plohij, La foi de Nalewajko : les cosaques et la religion dans l'Ukraine de la première modernité], Kiev : Kritika, 2006.

99. En témoignent les actions menées par certains archiprêtres en faveur d'un rapprochement avec la Moscovie ou, au contraire, d'un renforcement des autonomies locales : Т. Яковлева, 
En renforçant le rôle des imaginaires politiques produits par la concurrence et les affrontements entre États, le cadre institutionnel de l'Hetmanat mit d'autant plus en relief la spécificité de son Église, dont les pratiques et les aspirations devenaient difficilement transposables au-delà des territoires qui relevaient de la juridiction cosaque. De cette manière, tout en assurant une forme de continuité avec les confréries ruthènes qui surent préserver la cohésion de l'Église kiévienne orthodoxe, les choix institutionnels faits par les élites zaporogues finirent par contribuer à l'éclatement de la métropolie kiévienne entre les juridictions, mais également entre des cultures confessionnelles devenues discordantes.

La division de la métropolie de Kiev entre les obédiences romaine et constantinopolitaine émergea à l'intérieur d'un réseau ecclésiastique très vaste et, dans le même temps, très éclaté localement sous l'effet du droit de patronage privé. Si la liberté de culte reconnue à la noblesse permit aux églises orthodoxes de se maintenir, elle constitua un obstacle à toute tentative de mettre en œuvre des réformes ecclésiastiques perçues comme contraires aux intérêts des propriétaires terriens. Ce poids des structures sociales de la République polono-lituanienne obligea chacun des deux camps à réinventer de nouvelles pratiques de gouvernement paroissial. Alors que l'Église uniate tenta d'introduire des réformes disciplinaires fondées sur les modèles latins, les orthodoxes renforcèrent la place des monastères et de l'élément laïc en réponse à la disparition de la hiérarchie épiscopale. Face à ce vide institutionnel, les confréries ruthènes nées vers la fin $d u X V I^{e}$ siècle sous la forme d'associations paroissiales orthodoxes continuèrent leur croissance au siècle suivant et servirent d'intermédiaires indispensables pour maintenir les liens entre les communautés locales et leurs clergés.

La différenciation « confessionnelle » entre uniates et orthodoxes fut donc étayée par des évolutions institutionnelles divergentes, qui insistaient sur le rôle de la paroisse comme lieu d'exercice du pouvoir spirituel du clergé ou, au contraire, comme traduction formalisée de la communauté locale des fidèles. Les innovations façonnées par les confréries ruthènes furent toutefois des solutions fragiles. Le retour des cadres traditionnels de l'Église orthodoxe dès 1633, puis leur partage entre la République polono-lituanienne et l'Hetmanat, après 1648, entraînèrent des reconstructions des structures ecclésiastiques, qui, tout en s'extrayant parfois des barrières confessionnelles, purent assimiler d'autres lignes de démarcation, fondées sur les rivalités entre États et l'attachement aux cultures politiques locales.

L'une des conséquences de ce phénomène fut de déplacer certains clivages structurels depuis les frontières ecclésiastiques entre obédiences vers les frontières entre entités politiques. La meilleure illustration en est le manuel pastoral à destination du clergé paroissial, rédigé en 1687 par l'évêque orthodoxe de L'viv Józef Szumlański sous le titre Metryka albo reiestr. Les réformes qui y étaient présentées (visites pastorales du clergé, convocation de synodes réguliers ou l'introduction des registres paroissiaux dans le diocèse) étaient le signe explicite du mimétisme

Гетьманщина в другій половині 50-х років хиII століття [T. Jakovleva, L'Hetmanat dans la seconde moitié des années 50 du XVII siècle], Kiev : Osnovi, 1998, p. 65-66. 
entre les clergés uniate et orthodoxe polono-lituanien, alors qu'au même moment l'Église orthodoxe de l'Hetmanat passait à son tour sous la juridiction moscovite et avait de plus en plus de mal à jouer un rôle de modèle pour le clergé orthodoxe de Pologne-Lituanie. En témoigne le ralliement à l'Union avec Rome de tous les diocèses orthodoxes de la Rive droite du Dniepr, entre 1691 et 1702 (Przemyśl, $L^{\prime}$ viv et Luc'k). Ce constat conduit alors à nuancer une image historiographique prégnante, qui décrit les évolutions internes des cadres ecclésiastiques comme une simple conséquence de l'affirmation des cultures confessionnelles concurrentes, produites par la différence dogmatique. L'analyse de la diffusion des savoirs administratifs relatifs au gouvernement paroissial tend à montrer que l'élaboration d'une mémoire institutionnelle dans les clergés orientaux - un processus qui ne put aboutir qu'au cours du XVIII ${ }^{\mathrm{e}}$ siècle - joua un rôle majeur dans l'évolution des représentations des communautés slaves étudiées, accentuant leur émiettement et rendant obsolète l'image médiévale de leur unité ${ }^{100}$.

tatarenko.laurent@gmail.com

Chercheur associé au CERCEC, EHESS, Paris

100. Sur l'émergence et la consolidation de nouveaux modèles confessionnels concurrents, au cours du XVIII ${ }^{\mathrm{e}}$ siècle, voir la réflexion présentée dans : B. Skiner, The Western Front of the Eastern Church; Uniate and Orthodox Conflict in Eighteenth-century Poland, Ukraine, Belarus and Russia, DeKalb : Northem Illinois University Press, 2009 et Gil, Skoczylas, Kościoty wschodnie, p. 253-426. 
